\title{
Dihydroisocoumarins, Naphthalenes, and Further Polyketides from Aloe vera and A. plicatilis: Isolation, Identification and Their 5-LOX/COX-1 Inhibiting Potency
}

\author{
Hans Wilhelm Rauwald ${ }^{1, *}$, Ralf Maucher ${ }^{1}$, Gerd Dannhardt ${ }^{2}$ and Kenny Kuchta ${ }^{1}$ \\ 1 Department of Pharmaceutical Biology, Leipzig University, Johannisallee 21-23, 04103 Leipzig, Germany \\ 2 Department of Pharmaceutical and Medicinal Chemistry, Johannes Gutenberg-University, \\ 55122 Mainz, Germany \\ * Correspondence: rauwald@rz.uni-leipzig.de
}

\section{check for} updates

Citation: Rauwald, H.W.; Maucher, R.; Dannhardt, G.; Kuchta, K. Dihydroisocoumarins, Naphthalenes, and Further Polyketides from Aloe vera and A. plicatilis: Isolation, Identification and Their 5-LOX/ COX-1 Inhibiting Potency. Molecules 2021, 26, 4223. https://doi.org/ $10.3390 /$ molecules 26144223

Academic Editor:

Celestino Santos-Buelga

Received: 20 May 2021

Accepted: 3 July 2021

Published: 12 July 2021

Publisher's Note: MDPI stays neutral with regard to jurisdictional claims in published maps and institutional affiliations.

Copyright: (C) 2021 by the authors Licensee MDPI, Basel, Switzerland. This article is an open access article distributed under the terms and conditions of the Creative Commons Attribution (CC BY) license (https:// creativecommons.org/licenses/by/ $4.0 /)$.

\begin{abstract}
The present study aims at the isolation and identification of diverse phenolic polyketides from Aloe vera (L.) Burm.f. and Aloe plicatilis (L.) Miller and includes their 5-LOX/COX-1 inhibiting potency. After initial Sephadex-LH20 gel filtration and combined silica gel 60- and RP18$\mathrm{CC}$, three dihydroisocoumarins (nonaketides), four 5-methyl-8-C-glucosylchromones (heptaketides) from A. vera, and two hexaketide-naphthalenes from A. plicatilis have been isolated by means of HSCCC. The structures of all polyketides were elucidated by ESI-MS and $2 \mathrm{D}{ }^{1} \mathrm{H} /{ }^{13} \mathrm{C}-\mathrm{NMR}$ (HMQC, HMBC) techniques. The analytical/preparative separation of $3 R$-feralolide, $3^{\prime}-O-\beta$-D-glucopyranosyland the new $6-O-\beta$-D-glucopyranosyl-3R-feralolide into their respective positional isomers are described here for the first time, including the assignment of the $3 R$-configuration in all feralolides by comparative $\mathrm{CD}$ spectroscopy. The chromones 7-O-methyl-aloesin and 7-O-methyl-aloeresin $\mathrm{A}$ were isolated for the first time from $A$. vera, together with the previously described aloesin (syn. aloeresin B) and aloeresin D. Furthermore, the new 5,6,7,8-tetrahydro-1-O- $\beta$-D-glucopyranosyl- 3,6Rdihydroxy- $8 R$-methylnaphtalene was isolated from $A$. plicatilis, together with the known plicataloside. Subsequently, biological-pharmacological screening was performed to identify Aloe polyketides with anti-inflammatory potential in vitro. In addition to the above constituents, the anthranoids (octaketides) aloe emodin, aloin, $6^{\prime}$-(E)-p-coumaroyl-aloin $\mathrm{A}$ and B, and $6^{\prime}$-(E)-p-coumaroyl-7-hydroxy-8-Omethyl-aloin A and B were tested. In the COX-1 examination, only feralolide $(10 \mu \mathrm{M})$ inhibited the formation of MDA by $24 \%$, whereas the other polyketides did not display any inhibition at all. In the 5-LOX-test, all aloin-type anthranoids $(10 \mu \mathrm{M})$ inhibited the formation of $\mathrm{LTB}_{4}$ by about $25-41 \%$. Aloesin also displayed $10 \%$ inhibition at $10 \mu \mathrm{M}$ in this in vitro setup, while the other chromones and naphthalenes did not display any activity. The present study, therefore, demonstrates the importance of low molecular phenolic polyketides for the known overall anti-inflammatory activity of Aloe vera preparations.
\end{abstract}

Keywords: Aloe vera; Aloe plicatilis; dihydroisocoumarins; naphthalenes; polyketides; anti-inflammatory activity; COX-1/5-LOX

\section{Introduction}

Secondary metabolites in the genus Aloe are characterized by various polyketide constituents, such as naphthalenes (hexaketides), chromones (heptaketides), anthrones/ anthraquinones (octaketides), and nonaketides such as feralolide [1]. Continuing our chemical investigation on polyketides from Aloe species [2-7], the present study aims at the isolation and identification of diverse phenolic polyketides from Aloe vera (L.) Burm.f. and A. plicatilis (L.) Miller and includes a screening of their 5-LOX/COX-1 inhibiting potency. Thus, from $A$. vera, three dihydroisocoumarins were isolated and identified, namely, $3 R$-feralolide (1), $3^{\prime}-O-\beta$-D-glucopyranosyl-3R-feralolide (2), and the new $6-O-\beta$ D-glucopyranosyl-3R-feralolide (3), together with four 5-methyl-8-C-glucosylchromones, 
namely, 7-O-methyl-aloesin (5) and 7-O-methyl-aloeresin A (6), both detected for the first time in $A$. vera, with the known aloesin (4) and aloeresin D (7) (for structural formulas, see Figure 1). Furthermore, the new 5,6,7,8-tetrahydro-1-O- $\beta$-D-glucopyranosyl-3,6Rdihydroxy-8R-methylnaphtalene (9) was isolated from A. plicatilis, together with the known plicataloside (8). As A. vera has traditionally been used, e.g., to promote wound healing, a biological-pharmacological screening was performed to identify Aloe polyketides with antiinflammatory potential in vitro. Additionally, six anthranoids isolated from A. vera, and previously described by our group [2-7], were tested, namely, $6^{\prime}-O-(E)$-coumaroyl-aloin $\mathrm{A}(\mathbf{1 2})$ and its diastereomer B (13), 6'-O-(E)-coumaroyl-7-hydroxy-8-O-methyl-aloin A (14) and its diastereomer B (15), together with aloe emodin (10) and aloins A/B (11). All compounds were tested in an in vitro system for activity on the $\mathrm{LTB}_{4}$ and MDA inflammatory pathways as we previously described [8-11].

For the new tetralin derivative (9), obtained from A. plicatilis, and for the three dihydroisocoumarins, no anti-inflammatory activities have yet been reported. Speranza et al. [12] isolated feralolide (3-(2'-acetyl-5'-hydroxyphenyl)methyl-3,4-dihydro-8hydroxy-2(1H)-benzopyran-1-on) from the A. ferox drug, and Veitch et al. [13] 3'-O- $\beta$-Dglucopyranosyl-feralolide from fresh leaves of $A$. hildebrandii. These structures, including their $3 R$ configuration, were preliminarily published by our group $[14,15]$ and recently confirmed in the flowers of $A$. arborescens [16]. Feralolide was later rediscovered in $A$. vera [17] and in A. hijazensis [18]. Especially strong anti-inflammatory effects were reported for aloesin derivatives [19-21], including the COX-2 inhibiting activity of aloesin itself [22]. Its derivatives, the two 7-O-methyl-aloesins $(5,6)$, had firstly been reported from $\mathrm{A}$. rupestris [23] and were newly found here in A. vera. The anthranoid octaketides (10-15) have been isolated in our lab as mentioned, and were discussed previously [2-7]. Only sporadic in vitro and in vivo experiments on the anti-inflammatory activity of single low-molecular constituents of $A$. vera leaves have been published, e.g., aloenine, aloe emodin, aloins $\mathrm{A} / \mathrm{B}$, or 2'-O-(E)-cinnamoyl-aloesinol [24]. Therefore, related polyketides might be promising leads as potential inhibitors of inflammatory pathways. Regarding used phytochemical methods, the isolation of 15 polyketides was mainly performed by means of HSCCC, after initial sephadex LH-20 gel filtration and combined silicagel-60/RP18-CC. Their structures were elucidated mainly by ESI-MS and $2 \mathrm{~d}-{ }^{1} \mathrm{H} /{ }^{13} \mathrm{C}-\mathrm{NMR}$ techniques, including HMQC and $\mathrm{HMBC}$ experiments, as well as CD spectroscopy. 

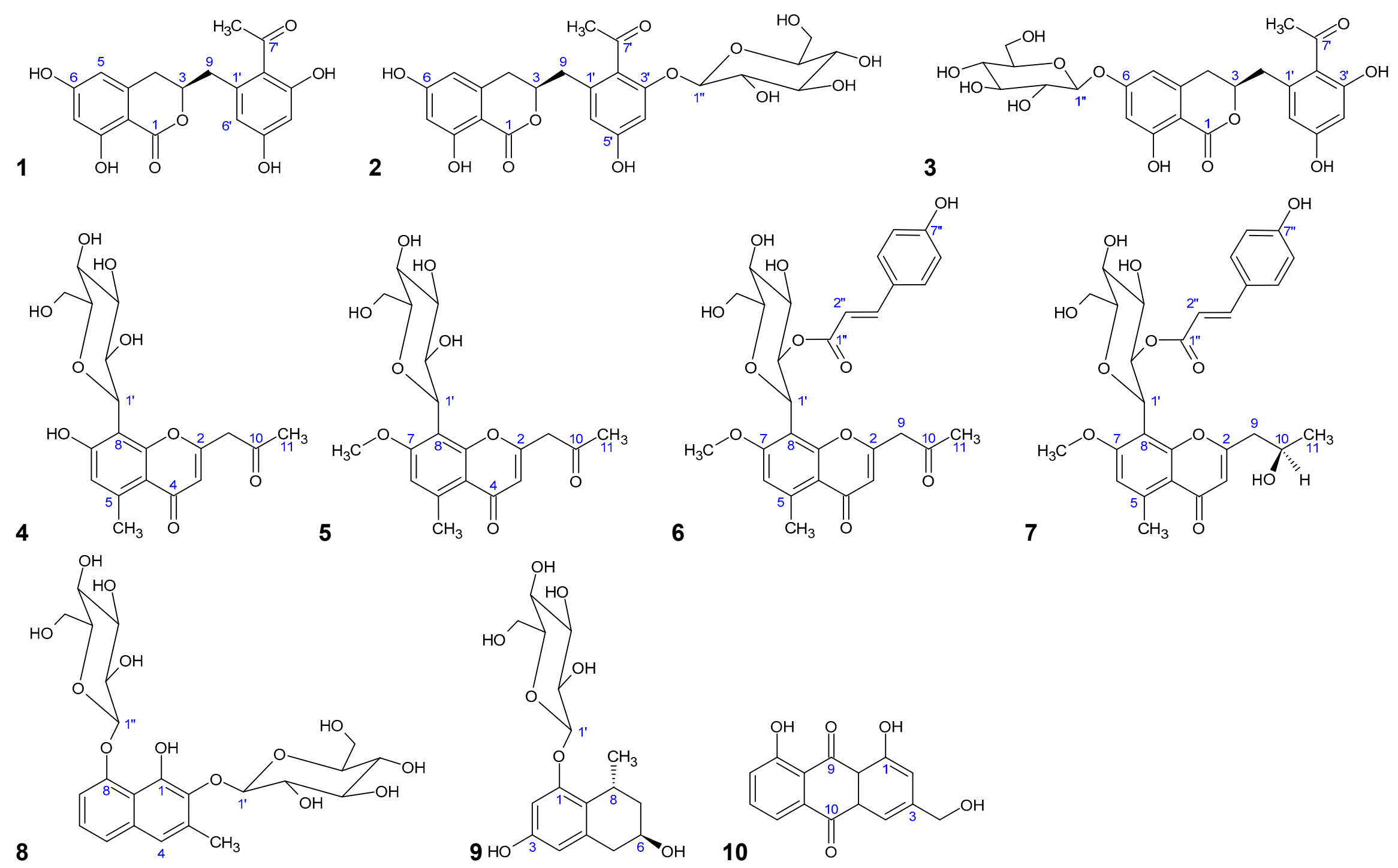

Figure 1. Cont. 


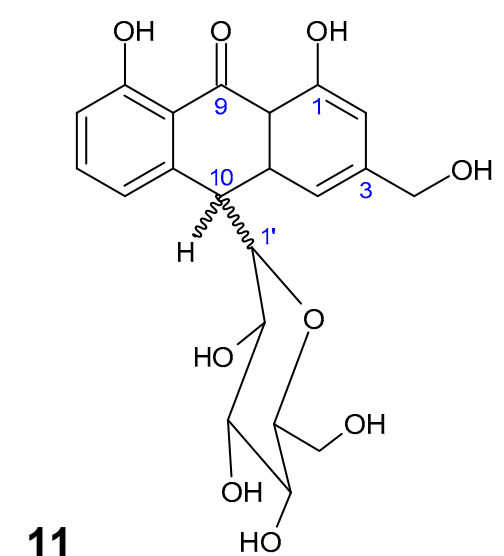

11

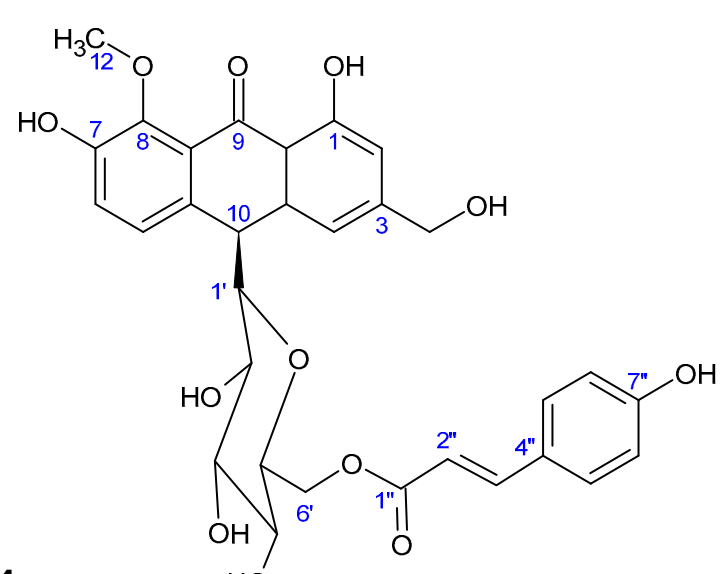

$\mathrm{HO}$
14

$\mathrm{HO}$
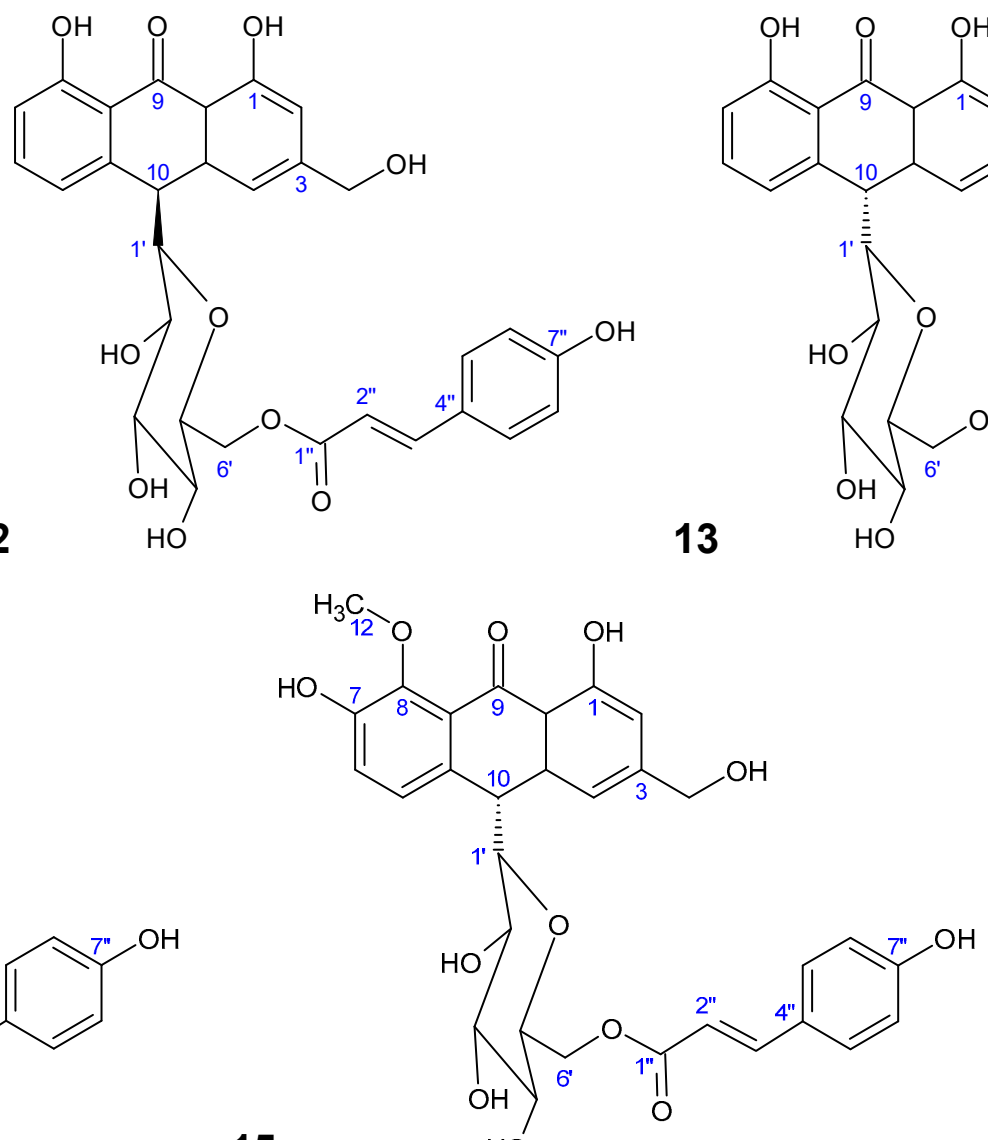

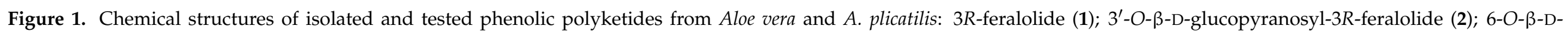

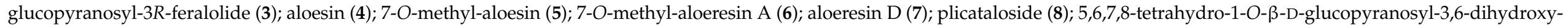

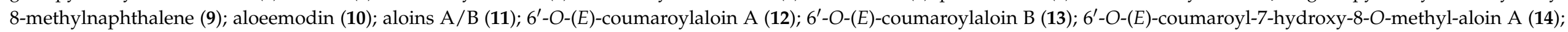
6'-O-(E)-coumaroyl-7-hydroxy-8-O-methyl-aloin B (15) 


\section{Results and Discussion}

\subsection{Phytochemical Investigations on A. vera}

The three dihydroisocoumarins, isolated for the first time from Aloe vera (L.) Burm.f., were identified by the following ${ }^{1} \mathrm{H} /{ }^{13} \mathrm{C}-\mathrm{NMR}$ and ESI-MS results.

3R-feralolide; (3R-(2'-acetyl-5'-hydroxyphenyl)methyl-3,4-dihydro-8-hydroxy- 2(1H)benzopyran-1-on) (1):

${ }^{1} \mathrm{H}-\mathrm{NMR}(\mathrm{MeOD}, \delta[\mathrm{ppm}]): 6.31\left(\mathrm{~d}, 1 \mathrm{H}, \mathrm{H}-6{ }^{\prime},{ }^{4} J_{\mathrm{H}, \mathrm{H}}=2.2 \mathrm{~Hz}\right) ; 6.27\left(\mathrm{~d}, 1 \mathrm{H}, \mathrm{H}-4^{\prime},{ }^{4} J_{\mathrm{H}, \mathrm{H}}\right.$ $=2.2 \mathrm{~Hz}) ; 6.22\left(\mathrm{~d}, 1 \mathrm{H}, \mathrm{H}-5,{ }^{4} J_{\mathrm{H}, \mathrm{H}}=2.1 \mathrm{~Hz}\right) ; 6.20\left(\mathrm{~d}, 1 \mathrm{H}, \mathrm{H}-7,{ }^{4} J_{\mathrm{H}, \mathrm{H}}=2.2 \mathrm{~Hz}\right) ; 4.74(\mathrm{~m}, 1 \mathrm{H}$, $\mathrm{H}-3) ; 3.03,2.89$ (2xm, 4H, 2xH-4, 2xH-9); 2.45 (s, 3H, 3xH-8 ${ }^{\prime}$ ). ${ }^{13} \mathrm{C}-\mathrm{NMR}(\mathrm{MeOD}, \delta$ [ppm]): 205.73 (C-7'); 170.26 (C-1); 165.21 (C-6); 164.54 (C-8); 159.09 (C-3'); 160.36 (C-5'); 142.25

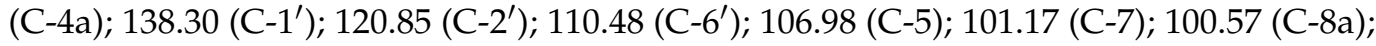
$101.47\left({\mathrm{C}-4^{\prime}}^{\prime}\right) ; 80.41$ (C-3); 38.61 (C-9); 32.51 (C-4); 31.91 (C-8'). ESI-MS: 362 [M + NH $]^{+}, 367$ $[\mathrm{M}+\mathrm{Na}]^{+}, 381[\mathrm{M}+\mathrm{K}]^{+}$.

3'-O- $\beta$-D-glucopyranosyl-3R-feralolide; (3R-(2'-acetyl-5'-hydroxyphenyl-3'-O- $\beta$-D- glucopyranosyl)methyl-3,4-dihydro-8-hydroxy-2(1H)-benzopyran-1-on) (2):

${ }^{1} \mathrm{H}-\mathrm{NMR}$ (DMSO-d 6 , $\delta$ [ppm]): 10.93, 9.96 (br, 2H, OH-6, OH-8); 6.53 (d, 1H, H-4', $\left.{ }^{4} J_{\mathrm{H}, \mathrm{H}}=1.9 \mathrm{~Hz}\right) ; 6.41\left(\mathrm{~d}, 1 \mathrm{H}, \mathrm{H}-6^{\prime},{ }^{4} J_{\mathrm{H}, \mathrm{H}}=1.9 \mathrm{~Hz}\right) ; 6.18(\mathrm{~s}(\mathrm{br}), 1 \mathrm{H}, \mathrm{H}-5) ; 6.12(\mathrm{~s}(\mathrm{br}), 1 \mathrm{H}, \mathrm{H}-7)$; 4.86 (d, 1H, H-1", $\left.{ }^{3} J_{1,2}=7.9 \mathrm{~Hz}\right) ; 4.55$ (m, 1H, H-3); 3.69, 3.49 (m, 2H, 2xH-6" ); 3.50 (m, $\left.1 \mathrm{H}, \mathrm{H}-5^{\prime \prime}\right) ; 3.23$ (m, 1H, H-3"); 3.21 (m, 1H, H-2"); 3.19 (m, 1H, H-4"); 2.92, 2.83 (2xm, 2H, 2xH-9); 2.81, 2.80 (2xm, 2H, 2xH-4); 2.49 (s, 3H, 3xH-8 $\left.{ }^{\prime}\right) .{ }^{13} \mathrm{C}-\mathrm{NMR}\left(\mathrm{DMSO}-\mathrm{d}_{6}, \delta\right.$ [ppm]): 204.34 (C-7'); 168.60 (C-1); 163.03 (C-6); 162.56 (C-8), 158.90 (C-5'); 157.17 (C-3'); 141.75 (C-8a); 137.06 (C-1'); 120.99 (C-2'); 109.60 (C-6'); 107.21 (C-5); 99.44 (C-7); 101.75 (C-4'); 101.11 (C-1"); 99.33 (C-5a); 79.66 (C-3); 76.66 (C-3"); 75.85 (C-2"); 72.75 (C-5"); 69.33 (C-4"); 60.37 (C-6"); 37.23 (C-9); 31.91 (C-8'); 31.85 (C-4). ESI-MS: 529 [M + Na] ${ }^{+}, 345$ [M-Glucose] ${ }^{+}$.

6-O- $\beta$-D-glucopyranosyl-3R-feralolide; ((3R)-3,4-dihydro-8-hydroxy-3-(2' -acetyl- 6-O$\beta$-D-glucopyranosyl-3',5'-dihydroxyphenyl)methyl-1H-[2]-benzopyran-1-on) (3):

${ }^{1} \mathrm{H}-\mathrm{NMR}$ (DMSO-d 6 , $\delta$ [ppm]): 11.04 (br, 1H, OH-8); 10.02, 9.80 (br, 2H, OH-5', OH$\left.3^{\prime}\right) ; 6.52\left(\mathrm{~d}, 1 \mathrm{H}, \mathrm{H}-5,{ }^{4} J_{\mathrm{H}, \mathrm{H}}=1.9 \mathrm{~Hz}\right) ; 6.47\left(\mathrm{~d}, 1 \mathrm{H}, \mathrm{H}-7,{ }^{4} J_{\mathrm{H}, \mathrm{H}}=1.9 \mathrm{~Hz}\right) ; 6.30\left(\mathrm{~d}, 1 \mathrm{H}, \mathrm{H}-4^{\prime}\right.$, $\left.{ }^{4} J_{\mathrm{H}, \mathrm{H}}=1.9 \mathrm{~Hz}\right) ; 6.23\left(\mathrm{~d}, 1 \mathrm{H}, \mathrm{H}-6{ }^{\prime},{ }^{4} J_{\mathrm{H}, \mathrm{H}}=1.9 \mathrm{~Hz}\right) ; 5.33\left(\mathrm{~s}(\mathrm{br}), 1 \mathrm{H}, \mathrm{OH}-2{ }^{\prime \prime}\right) ; 5.10$ (s(br), $\left.1 \mathrm{H}, \mathrm{OH}-3^{\prime \prime}\right) ; 5.04$ (s(br), 1H, OH-4"); 5.00 (d, 1H, H-1", $\left.{ }^{3} J_{1,2,}=7.9 \mathrm{~Hz}\right) ; 4.72$ (m, 1H, H3); 4.56 (s(br), 1H, OH-6"); 3.67, $3.46\left(\mathrm{~d}, \mathrm{dd}, 2 \mathrm{H}, 2 \mathrm{xH}-6{ }^{\prime \prime}, 3{ }^{3} \mathrm{~J}_{\mathrm{H}, \mathrm{H}}=5.3 \mathrm{~Hz},{ }^{3} \mathrm{~J}_{\mathrm{H}, \mathrm{H}}<1 \mathrm{~Hz}\right.$, $\left.{ }^{3} J_{\mathrm{H}, \mathrm{H}}=11.4 \mathrm{~Hz}\right) ; 3.39\left(\mathrm{~m}, 1 \mathrm{H}, \mathrm{H}-5^{\prime \prime}\right) ; 3.22\left(\mathrm{dd}, 1 \mathrm{H}, \mathrm{H}-2^{\prime \prime},{ }^{3} \mathrm{~J}_{2,3}=8.6 \mathrm{~Hz}\right) ; 3.27$ (dd, $1 \mathrm{H}, \mathrm{H}-3$ ", $\left.{ }^{3} J_{\mathrm{H}, \mathrm{H}}=9.0 \mathrm{~Hz}\right) ; 3.16\left(\mathrm{dd}, 1 \mathrm{H}, \mathrm{H}-4^{\prime \prime},{ }^{3} J_{\mathrm{H}, \mathrm{H}}=9.0 \mathrm{~Hz}\right) ; 2.92,2.90(2 \mathrm{xm}, 2 \mathrm{H}, 2 \mathrm{xH}-4) ; 2.97,2.89$ (2xm, 2H, 2xH-9); 2.49 (s, 3H, 3xH-8 $) .{ }^{13} \mathrm{C}-\mathrm{NMR}\left(\mathrm{DMSO}_{6}, \delta\right.$ [ppm]): 203.37 (C-7'); 168.80 (C-1); 163.23 (C-6); 162.89 (C-8); 159.39 (C-5"); 157.78 (C-3"); 141.69 (C-4a); 137.00 (C-1"); 120.70 (C-2"); 109.79 (C-6"); 107.17 (C-5); 102.40 (C-8a); 101.81 (C-7); 101.37 (C-4"); 99.52 $\left(\mathrm{C}-1^{\prime}\right) ; 79.67$ (C-3); $76.39\left(\mathrm{C}-3^{\prime}\right) ; 77.03\left(\mathrm{C}-5^{\prime}\right) ; 73.02\left(\mathrm{C}-2^{\prime}\right) ; 69.49\left(\mathrm{C}-4^{\prime}\right) ; 60.53$ (C-6"); 37.65

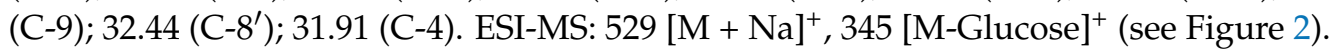

These experimental data are in good accordance with those published for the first isolation of feralolide (1) from $A$. ferox [12] and could be further validated by additional NOE measurements. The structure of $3^{\prime}-O-\beta$-D-glucopyranosyl-feralolide (2) was identified by the above given NMR data, in comparison with the literature [13] and additional NOE measurements, whereby the attachment of the glucosyl moiety at $\mathrm{C}^{\prime}-\mathrm{OH}$ could be verified for the first time in the present study. The structure of the new 6-O- $\beta$-D-glucopyranosylferalolide (3) was identified by the above-given NMR, including HMBC data and additional NOE measurements. In contrast to $3^{\prime}-O-\beta$-D-glucopyranosyl-feralolide (2), the attachment of the glucosyl moiety at $\mathrm{C} 6-\mathrm{OH}$ was determined by the corresponding $\mathrm{HMBC}$ and $\mathrm{NOE}$ data (see Figures 3 and 4). All feralolides (1, 2, and 3) show identical negative and positive signs in the comparison of their CD spectra, thus enabling a clear identification of their $3 R$ configuration (Figure 4 ). In terms of quantity, aglycone $\mathbf{1}$ is the major feralolide in the A. vera drugs, while glucosides 3 and 2 are present in a ratio of $2.5: 1$, as shown by HPLC separation (Figure 5). 


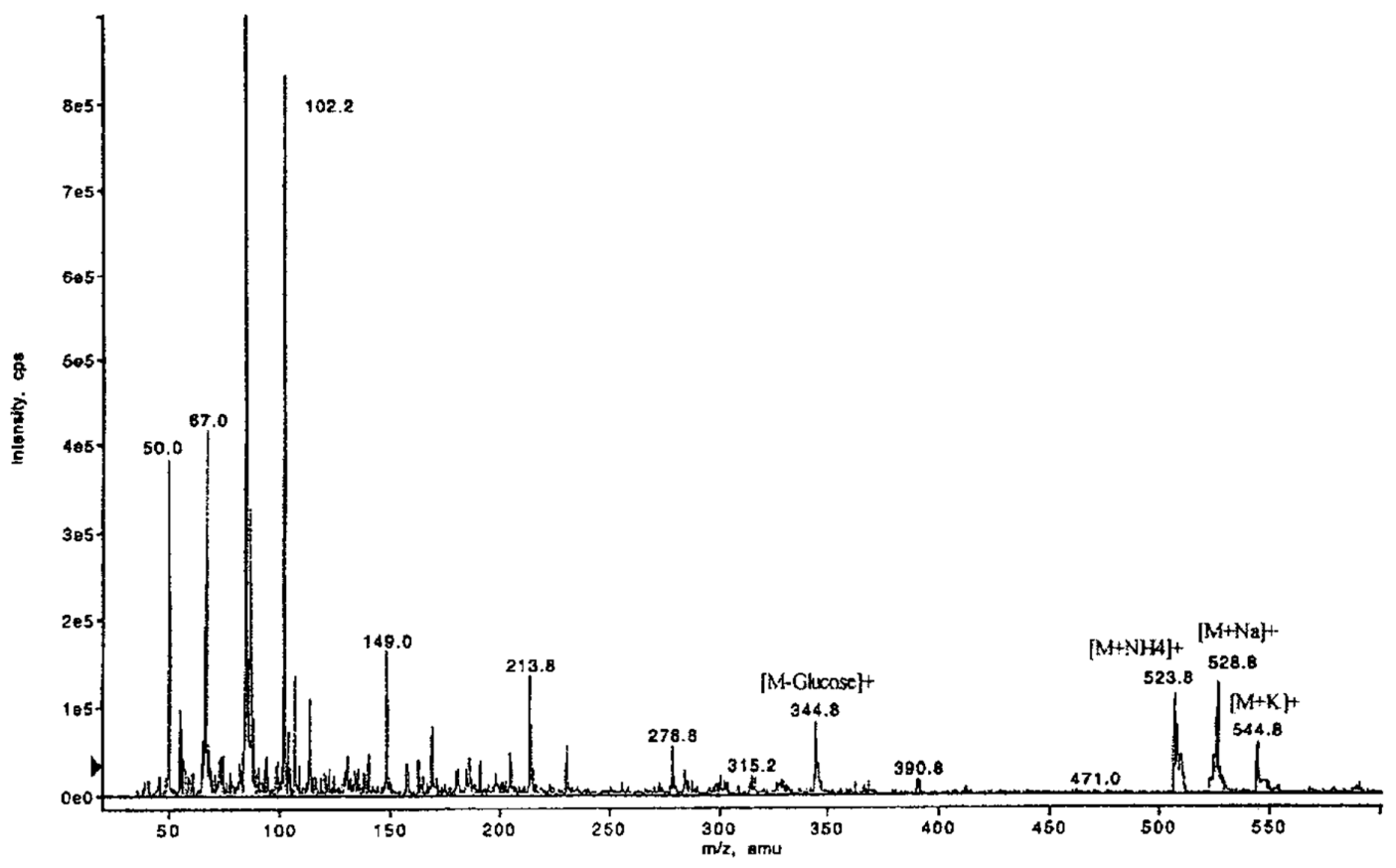

Figure 2. ESI-MS of 6-O- $\beta$-D-glucopyranosyl-feralolide (3). Experimental conditions: see text.
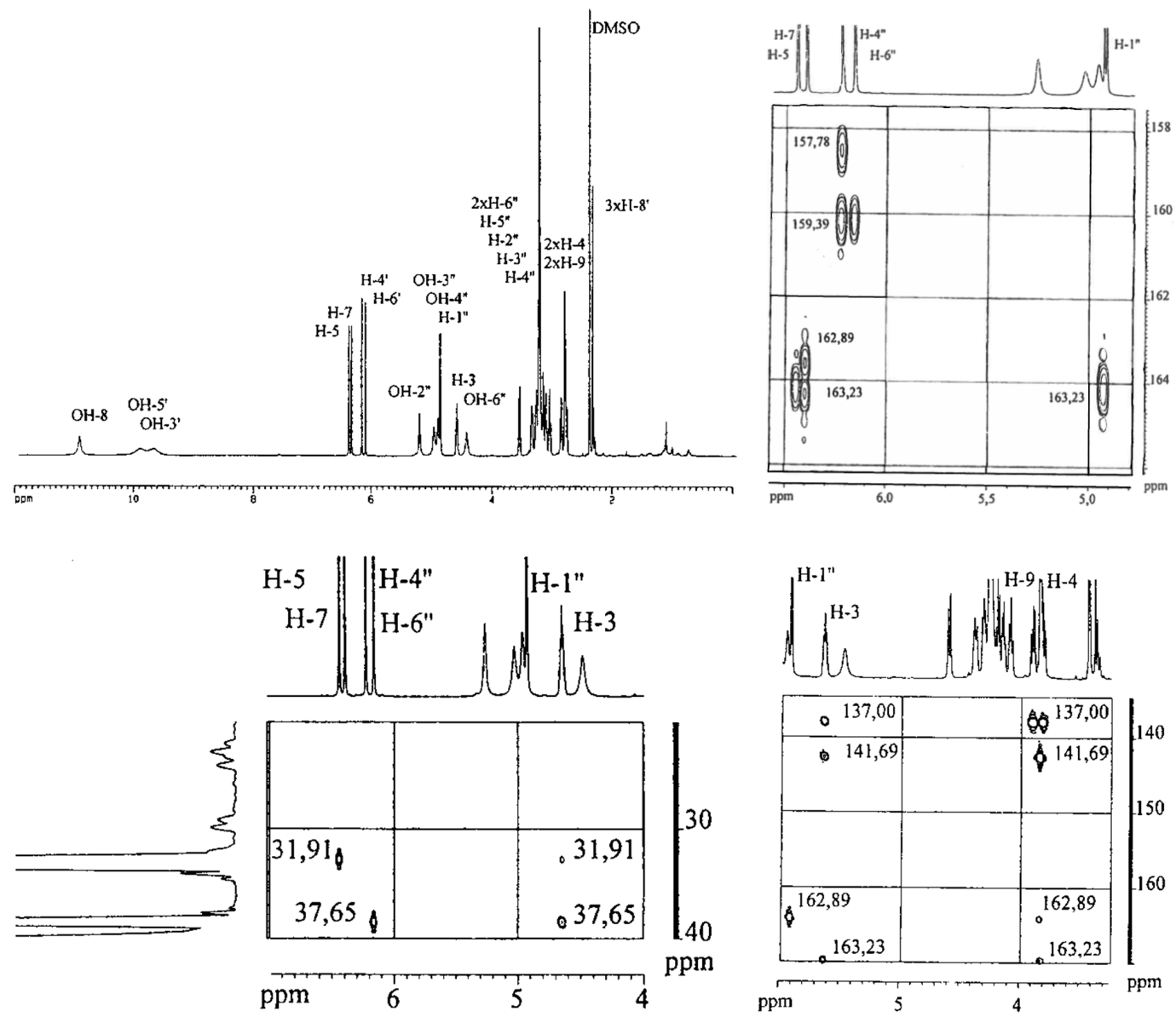

Figure 3. Images showing the $300 \mathrm{MHz}^{-1} \mathrm{H}-\mathrm{NMR}$ spectra of $6-\mathrm{O}-\beta$-D-glucopyranosyl-feralolide (3) (DMSO- $\left.\mathrm{d}_{6}\right)$, with $\mathrm{HMBC}$ excerpts for 20-40 ppm and 130-165 ppm. 

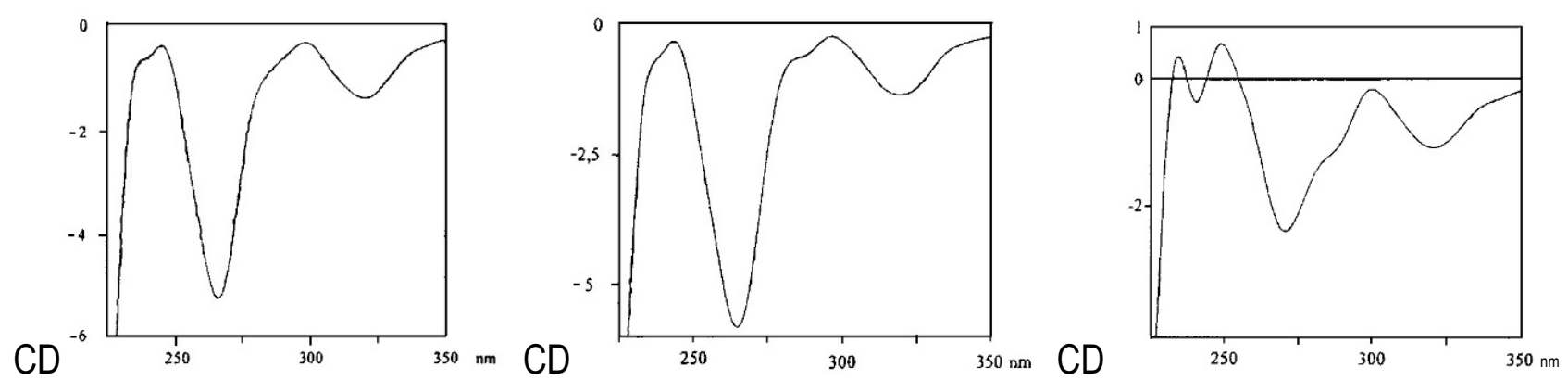

Figure 4. Comparison of the CD spectra of feralolide (1) (left), 6-O- $\beta$-D-glucopyranosyl-feralolide (3) (center) and $3^{\prime}$-O- $\beta$-Dglucopyranosyl-feralolide (2) (right) for configurational $3 R$ determination.

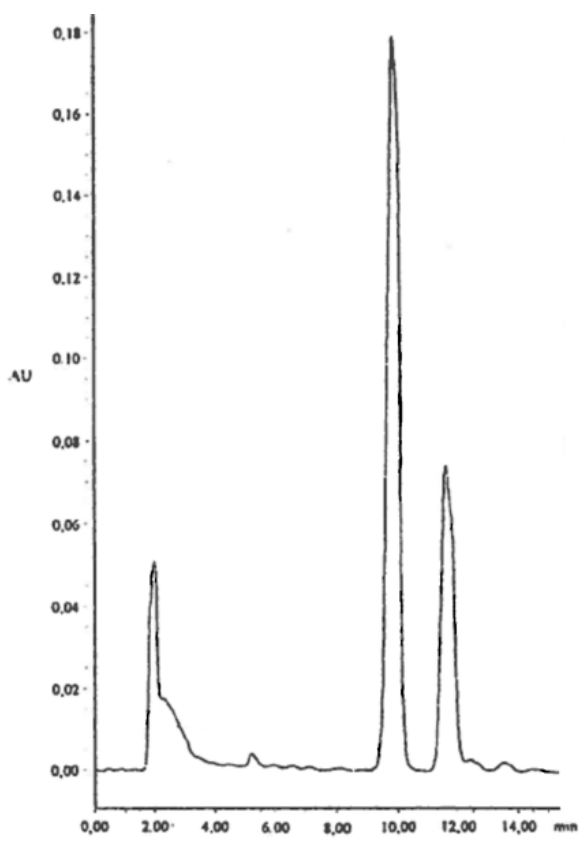

Figure 5. Semipreparative HPLC separation (for conditions, see text) with resolution of the positional isomers 6-O- $\beta$-D-glucopyranosyl-feralolide $(3)\left(t_{R}=10 \mathrm{~min}\right)$ and $3^{\prime}-O-\beta$-D-glucopyranosyl-feralolide (2) $\left(t_{R}=12 \mathrm{~min}\right)$ relative to their approximately $2.5: 1$ ratio in the $A$. vera drug is here reported for the first time.

In detail, the chromatographic and spectroscopic data of (2) and (3) displayed a high degree of similarity. The only significant difference between these two substances is the cross peak between the carbon atom C6 and the anomeric H1" in the HMBC spectrum in the latter compound, which proves the bond of the glucose moiety to the $\mathrm{C} 6$ carbon. The protons at $\mathrm{C} 5$ and $\mathrm{C} 7$ exhibit cross peaks with the carbons $\mathrm{C} 6$ and $\mathrm{C} 6 \& \mathrm{C} 8$, respectively. The protons at $C 4^{\prime}$ and $C 6^{\prime}$ display cross peaks with the carbons $C 3^{\prime} \& C 5^{\prime}$ and $C 5^{\prime}$, respectively (Figure 3). Further cross peaks observed in the HMBC spectrum are those between the protons at $\mathrm{C} 5$ and $\mathrm{C}^{\prime}$ and the carbons $\mathrm{C} 4$ and $\mathrm{C} 9$, respectively, as well as between the proton C3 and the carbons C4 \& C9 (Figure 3). The methylene groups of C4 and C9 display further cross peaks with the carbons $\mathrm{C1}^{\prime}, \mathrm{C} 1, \mathrm{C} 4 \mathrm{a}$ (between $\mathrm{C} 4$ and $\mathrm{C} 5$ ), and C6. Finally, three further cross peaks appear between $\mathrm{H} 3$ and the carbon atoms $\mathrm{C}^{\prime}, \mathrm{C} 1$, and C4a (Figure 3). Judging both from the ESI-MS (Figure 2) and NMR data, the aglycone of 6 -O- $\beta$-D-glucopyranosyl-feralolide (3) could clearly be identified as feralolide. However, in contrast to $3^{\prime}-O-\beta$-D-glucopyranosyl-feralolide (2), the glucose moiety was demonstrated to be attached to the 6-position as an $O$-glycoside, as strongly hinted by the low-field shift of about 2 ppm observed for the ${ }^{13} \mathrm{C}$-NMR values at $\mathrm{C} 3^{\prime}$ of $3^{\prime}-\mathrm{O}-\beta$-D-glucopyranosyl-feralolide and $\mathrm{C} 6$ of $6-O-\beta-\mathrm{D}$-glucopyranosyl- feralolide, respectively. As far as the stereochemistry 
at C3 and C9 is concerned, the measured CD data are clearly identical to those of feralolide (Figure 4), proving all three molecules to exhibit an $R$-configuration. Therefore, (3R)-6$O-\beta$-D-glucopyranosyl- feralolide (3) was firstly isolated from Aloe spp. as a new natural product in the study at hand. As far as $3^{\prime}-O-\beta$-D-glucopyranosyl-feralolide (2) is concerned, its steric structure at the $\mathrm{C} 3$ carbon had not been reported when it was first discovered in $A$. hildebrandii by [13], and has now been established as $3 R$, recently independently confirmed from flowers of $A$. arborescens [16]. Surprisingly, feralolide (1) was recently found in A. vera gel in two Yemeni Aloe spp. by LC-MS [25], confirming our previous assumption from TLC experiments $[14,15]$ that dihydroisocoumarins are also gel constituents.

Regarding aloesin (4) and aloesin-type chromones in A. vera, 7-O-methyl-aloesin (5) and its 2'-O-p-coumaroyl-derivative 7-O-methyl-aloeresin A (6) have been isolated for the first time from this plant, besides aloeresin D (7), which was previously isolated by our group [3]. The occurrence of 5 and $\mathbf{6}$ was first described in Aloe marlothii A.Berger and Aloe rupestris Baker [23]. Their structures were investigated by 2d-NMR, HMBC, HMQC, and COSY, as well as ESI-MS, in our laboratory [14,15] (Figure 6).

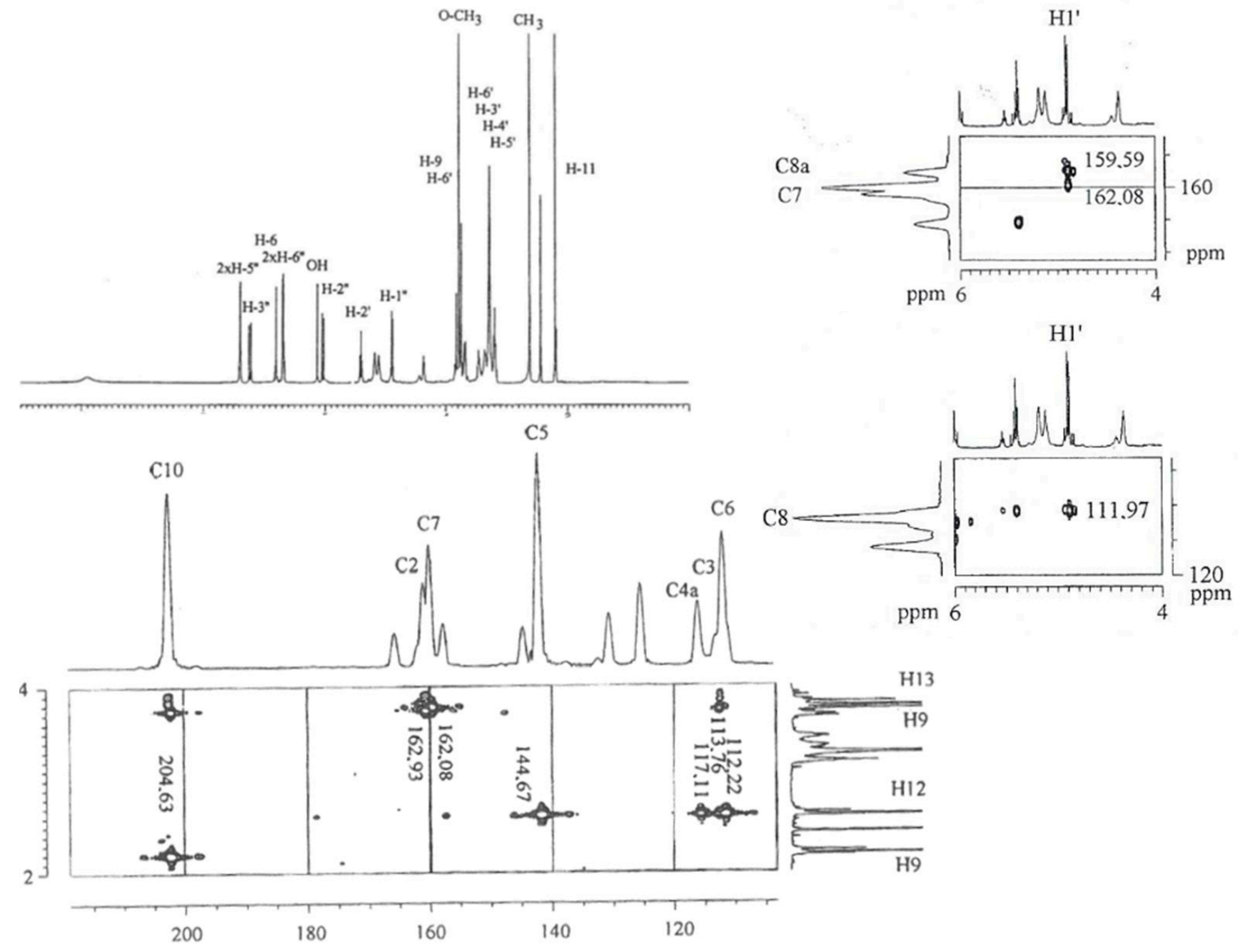

Figure 6. Images showing the $300 \mathrm{MHz}-{ }^{1} \mathrm{H}$ - and ${ }^{13} \mathrm{C}-\mathrm{NMR}$ spectra of 7-O-methyl-aloeresin A (6), with $\mathrm{HMBC}$ excerpts for 155-170 ppm, 105-120 ppm and 100-215 ppm.

7-O-methyl-aloesin; (2-acetonyl-8-C- $\beta$-D-glucopyranosyl-7-methoxy-5-methylchromone) (5):

${ }^{1} \mathrm{H}-\mathrm{NMR}\left(\mathrm{DMSO}-\mathrm{d}_{6}, \delta\right.$ [ppm]): 6.93 (s, 1H, H-6); 6.13 (s, 1H, H-3); 4.69 (d, 1H, H-1', $\left.{ }^{3} J_{\mathrm{H}, \mathrm{H}}=10.1 \mathrm{~Hz}\right) ; 3.88\left(\mathrm{~s}, 3 \mathrm{H}, \mathrm{O}-\mathrm{CH}_{3}\right) ; 3.76\left(\mathrm{dd}, 1 \mathrm{H}, \mathrm{H}-2^{\prime},{ }^{3} \mathrm{~J}_{\mathrm{H}, \mathrm{H}}=10.1 \mathrm{~Hz}\right) ; 3.72(\mathrm{~m}, 2 \mathrm{H}, \mathrm{H}-9)$; 3.68, $3.36\left(2 \mathrm{xm}, 2 \mathrm{H}, 2 \mathrm{xH}-6^{\prime}\right) ; 3.19\left(\mathrm{~m}, 1 \mathrm{H}, \mathrm{H}-5^{\prime}\right) ; 3.13\left(\mathrm{~m}, 1 \mathrm{H}, \mathrm{H}-3^{\prime}\right) ; 3.09\left(\mathrm{~m}, 1 \mathrm{H}, \mathrm{H}-4^{\prime}\right) ; 2.74$ 
(s, 3H, $\left.\mathrm{CH}_{3}\right) ; 2.21$ (s, 3H, 3xH-11). ${ }^{13} \mathrm{C}-\mathrm{NMR}$ (DMSO-d 6 , $\delta$ [ppm]): 204.48 (C-10); 182.10 (C-4); 162.93 (C-2); 162.70 (C-7); 159.28 (C-8a); 144.13 (C-5); 114.06 (C-4a); 113.43 (C-3); 113.36 (C-8); 113.09 (C-6); $82.50\left(\mathrm{C}-3^{\prime}\right) ; 80.16\left(\mathrm{C}-5^{\prime}\right) ; 74.67\left(\mathrm{C}-1^{\prime}\right) ; 72.80\left(\mathrm{C}-2^{\prime}\right) ; 72.07\left(\mathrm{C}-4^{\prime}\right)$; $63.28\left(\mathrm{C}-6^{\prime}\right) ; 56.94\left(\mathrm{O}-\mathrm{CH}_{3}\right) ; 49.60(\mathrm{C}-9) ; 30.01(\mathrm{C}-11) ; 23.64\left(\mathrm{CH}_{3}\right)$. ESI-MS: 431 [M + Na] ${ }^{+}$

7-O-methyl-aloeresin A; (2-acetonyl-8-C- $\beta$-D-(2-O- (E)-p-coumaroyl)glucopyranosyl7-methoxy-5-methylchromone) (6):

${ }^{1} \mathrm{H}-\mathrm{NMR}\left(\mathrm{DMSO}-\mathrm{d}_{6}, \delta\right.$ [ppm]): $9.90\left(\mathrm{~s}(\mathrm{br}), 1 \mathrm{H}, \mathrm{OH}-7^{\prime \prime}\right) ; 7.44\left(\mathrm{~d}, 2 \mathrm{H}, 2 \mathrm{xH}-5^{\prime \prime},{ }^{3} \mathrm{~J}_{\mathrm{H}, \mathrm{H}}=8.5 \mathrm{~Hz}\right)$; $7.28\left(\mathrm{~d}, 1 \mathrm{H}, \mathrm{H}-3^{\prime \prime},{ }^{3} \mathrm{~J}_{\mathrm{H}, \mathrm{H}}=15.7 \mathrm{~Hz}\right) ; 6.85(\mathrm{~s}, 1 \mathrm{H}, \mathrm{H}-6) ; 6.74\left(\mathrm{~d}, 2 \mathrm{H}, 2 \times \mathrm{H}^{\prime \prime}{ }^{\prime \prime},{ }^{3} \mathrm{~J}_{\mathrm{H}, \mathrm{H}}=8.5 \mathrm{~Hz}\right)$; $6.19(\mathrm{~s}, 1 \mathrm{H}, \mathrm{H}-3) ; 6.05\left(\mathrm{~d}, 1 \mathrm{H}, \mathrm{H}-2^{\prime \prime},{ }^{3} \mathrm{~J}_{\mathrm{H}, \mathrm{H}}=15.7 \mathrm{~Hz}\right) ; 5.46\left(\mathrm{dd}, 1 \mathrm{H}, \mathrm{H}-2^{\prime},{ }^{3} J_{\mathrm{H}, \mathrm{H}}=8.9 \mathrm{~Hz}\right) ; 5.23$ (s(br), 1H, OH-3'); $5.17\left(\mathrm{~s}(\mathrm{br}), 1 \mathrm{H}, \mathrm{OH}-4^{\prime}\right) ; 4.94\left(\mathrm{~d}, 1 \mathrm{H}, \mathrm{H}-1^{\prime},{ }^{3} J_{\mathrm{H}, \mathrm{H}}=10.1 \mathrm{~Hz}\right) ; 4.42(\mathrm{~s}(\mathrm{br}), 1 \mathrm{H}$, OH-6'); 3.84 (s, 3H, O-CH $\left.{ }_{3}\right) ; 3.80$ (s(br), 2H, H-9); 3.74, $3.41\left(2 \times m, 2 \mathrm{H}, 2 \mathrm{xH}-6^{\prime}\right) ; 3.51(\mathrm{~m}, 1 \mathrm{H}$, H-3'); 3.25 (m, 1H, H-4' $)$; $3.34\left(\mathrm{~m}, 1 \mathrm{H}, \mathrm{H}-5^{\prime}\right) ; 2.76\left(\mathrm{~s}, 3 \mathrm{H}, \mathrm{CH}_{3}\right) ; 2.26$ (s, 3H, H-11). ${ }^{13} \mathrm{C}-\mathrm{NMR}$ (DMSO-d 6 , $\delta$ [ppm]): $204.63(\mathrm{C}-10) ; 182.06(\mathrm{C}-4) ; 168.06\left(\mathrm{C}-1^{\prime \prime}\right) ; 162.93(\mathrm{C}-2) ; 162.08$ (C-7); 161.25 (C-7") ; 159.59 (C-8a); 145.25 (C-3"); 144.67 (C-5); 130.81 (C-5"); 127.00 (C-4"); 117.11 (C-4a); 116.66 (C-6"); 115.11 (C-2"); 113.76 (C-3); 112.22 (C-6); 111.97 (C-8); $82.80\left(\mathrm{C}-5^{\prime}\right)$; $77.81\left(\mathrm{C}-3^{\prime}\right) ; 73.89\left(\mathrm{C}-2^{\prime}\right) ; 72.53\left(\mathrm{C}-4^{\prime}\right) ; 72.14\left({\left.\mathrm{C}-1^{\prime}\right)}^{\prime} ; 63.33\left(\mathrm{C}-6^{\prime}\right) ; 57.12\left(\mathrm{O}-\mathrm{CH}_{3}\right) ; 49.10(\mathrm{C}-9)\right.$; 29.89 (C-11); $23.67\left(\mathrm{CH}_{3}\right)$. ESI-MS: $555[\mathrm{M}+\mathrm{H}]^{+}$

On the subject of the octaketides, the diastereomeric anthrone-C-glucosyl compounds of the aloin-type included in this biological screening have been preliminarily published [14,15], namely, 6'-O-(E)-coumaroyl-aloin A (12) and its B-diastereomer (13), $6^{\prime}-O-(E)$-coumaroyl-7hydroxy-8-O-methyl-aloin A (14), and its B-diastereomer (15), as well as aloe emodin (10) and aloins A/B (11).

\subsection{Phytochemical Investigations on A. plicatilis}

A methanol-water extract from freshly collected leaves of $A$. plicatilis was fractionated by combined silica gel and sephadex-LH20 CC, yielding the naphthalene derivatives 8 and 9. Derivative $\mathbf{8}$ was identified as the known substituted naphthalene diglucoside plicataloside [26]. Compound 9 was identified as the novel 1-methyltetralin derivative 5,6,7,8-tetrahydro-1-O- $\beta$-D-glucopyranosyl-3,6-dihydroxy-8-methylnaphtha- lene by the NMR data and additional NOE measurements. Three 1-methyltetralins were previously isolated from commercial Cape aloes. First, the aglycone feroxidin was characterized as 3,6,8-trihydroxy-1-methyltetralin with a $6 \mathrm{~S}$, 8S configuration $[27,28]$. Subsequently, the 3-O-glucoside (feroxin A), and its p-coumaric acid ester (feroxin B), were described [29]. Surprisingly, despite identical molecular masses, our isolated compound 9 from A. plicatilis is also a 1 -methyltetralin derivative, but with a $6 R, 8 R$ configuration. Extensive ${ }^{1} \mathrm{H} /{ }^{13} \mathrm{C}$ NMR experiments (Figure 7) and CD spectra with opposite signs (e.g., at $280 \mathrm{~nm}$; see Figure 8) to the feroxins clearly demonstrate that 9 displays the opposite sterical configuration, as compared to feroxin A. Additionally, the glucosylation has not taken place at the alcoholic hydroxyl at $\mathrm{C} 6$, as in feroxin A, but at the phenolic 1-OH, as also demonstrated by various NMR measurements.

5,6,7,8-tetrahydro-1-O- $\beta$-D-glucopyranosyl-3,6-dihydroxy-8-methylnaphthalene (9):

${ }^{1} \mathrm{H}-\mathrm{NMR}$ (DMSO-d 6 , $\delta$ [ppm]): 8.93 (s, 1H, OH-3); 6.34 (s, 1H, H-2); 6.11 (s, 1H, H-4), 5.11 (s(br), 1H, OH-2'); 5.04 (s(br), 1H, OH-3'); 4.98 (s(br), 1H, OH-4' $) ; 4.78$ (d, 1H, H-1', $\left.{ }^{3} \mathrm{~J}_{\mathrm{H}, \mathrm{H}}=7.5 \mathrm{~Hz}\right) ; 4.66(\mathrm{~s}(\mathrm{br}), 1 \mathrm{H}, \mathrm{OH}-6) ; 4.51\left(\mathrm{~s}(\mathrm{br}), 1 \mathrm{H}, \mathrm{OH}-6^{\prime}\right) ; 3.94(\mathrm{~m}, 1 \mathrm{H}, \mathrm{H}-6) ; 3.68,3.50$ $\left(2 \mathrm{xd}, 2 \mathrm{H}, 2 \mathrm{xH}-6^{\prime},{ }^{3} \mathrm{~J}_{\mathrm{H}, \mathrm{H}}=11.24 \mathrm{~Hz}\right) ; 3.29\left(\mathrm{~m}, 1 \mathrm{H}, \mathrm{H}-3^{\prime}\right) ; 3.26\left(\mathrm{~m}, 1 \mathrm{H}, \mathrm{H}-2^{\prime}\right) ; 3.24\left(\mathrm{~m}, 1 \mathrm{H}, \mathrm{H}-5^{\prime}\right)$; $3.21\left(\mathrm{~s}, 1 \mathrm{H}, \mathrm{H}-4^{\prime}\right) ; 3.12(\mathrm{~m}, 1 \mathrm{H}, \mathrm{H}-8) ; 2.85,2.40\left(2 \mathrm{xdd}, 2 \mathrm{H}, 2 \times \mathrm{H}-5,{ }^{3} \mathrm{~J}_{\mathrm{H}, \mathrm{H}}=10.34 \mathrm{~Hz}\right) ; 1.76(\mathrm{~d}$, $\left.1 \mathrm{H}, \mathrm{H}-7,{ }^{3} \mathrm{~J}_{\mathrm{H}, \mathrm{H}}=11.77 \mathrm{~Hz}\right) ; 1.52(\mathrm{~m}, 1 \mathrm{H}, \mathrm{H}-7) ; 1.16\left(\mathrm{~d}, 3 \mathrm{H}, \mathrm{CH}_{3},{ }^{3} \mathrm{~J}_{\mathrm{H}, \mathrm{H}}=6.93 \mathrm{~Hz}\right) .{ }^{13} \mathrm{C}-\mathrm{NMR}$ (DMSO-d ${ }_{6}, \delta$ [ppm]): 156.73 (C-3); 156.62 (C-1); 137.07 (C-4a); 121.42 (C-8a); 109.29 (C-4); $101.03\left(\mathrm{C}-1^{\prime}\right) ; 100.97(\mathrm{C}-2) ; 77.91\left(\mathrm{C}-3^{\prime}\right) ; 77.77\left(\mathrm{C}-5^{\prime}\right) ; 74.26\left(\mathrm{C}-2^{\prime}\right) ; 70.50\left(\mathrm{C}-4^{\prime}\right) ; 62.80(\mathrm{C}-6)$; $61.50\left(\mathrm{C}-6^{\prime}\right) ; 40.76(\mathrm{C}-7) ; 40.40(\mathrm{C}-5) ; 28.62(\mathrm{C}-8) ; 22.93\left(\mathrm{CH}_{3}\right)$. ESI-MS: $374\left[\mathrm{M}+\mathrm{NH}_{4}\right]^{+}, 379$ $[\mathrm{M}+\mathrm{Na}]^{+}, 395[\mathrm{M}+\mathrm{K}]^{+}$. 
A)

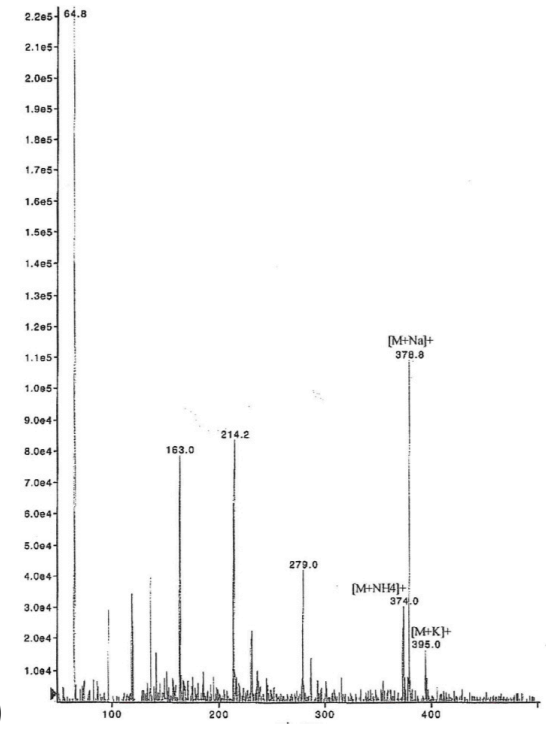

B)

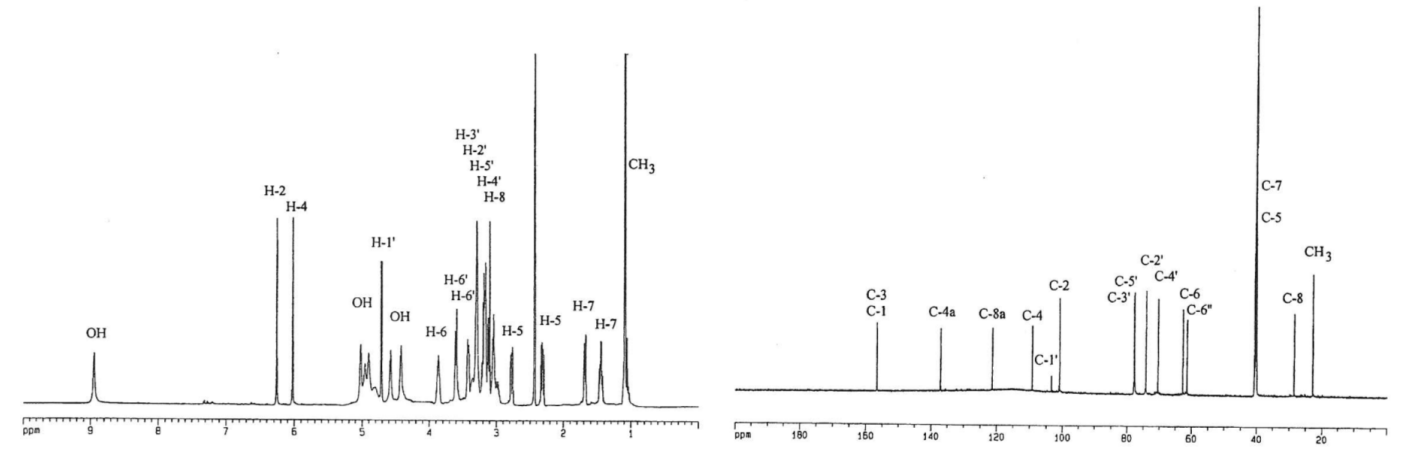

C)
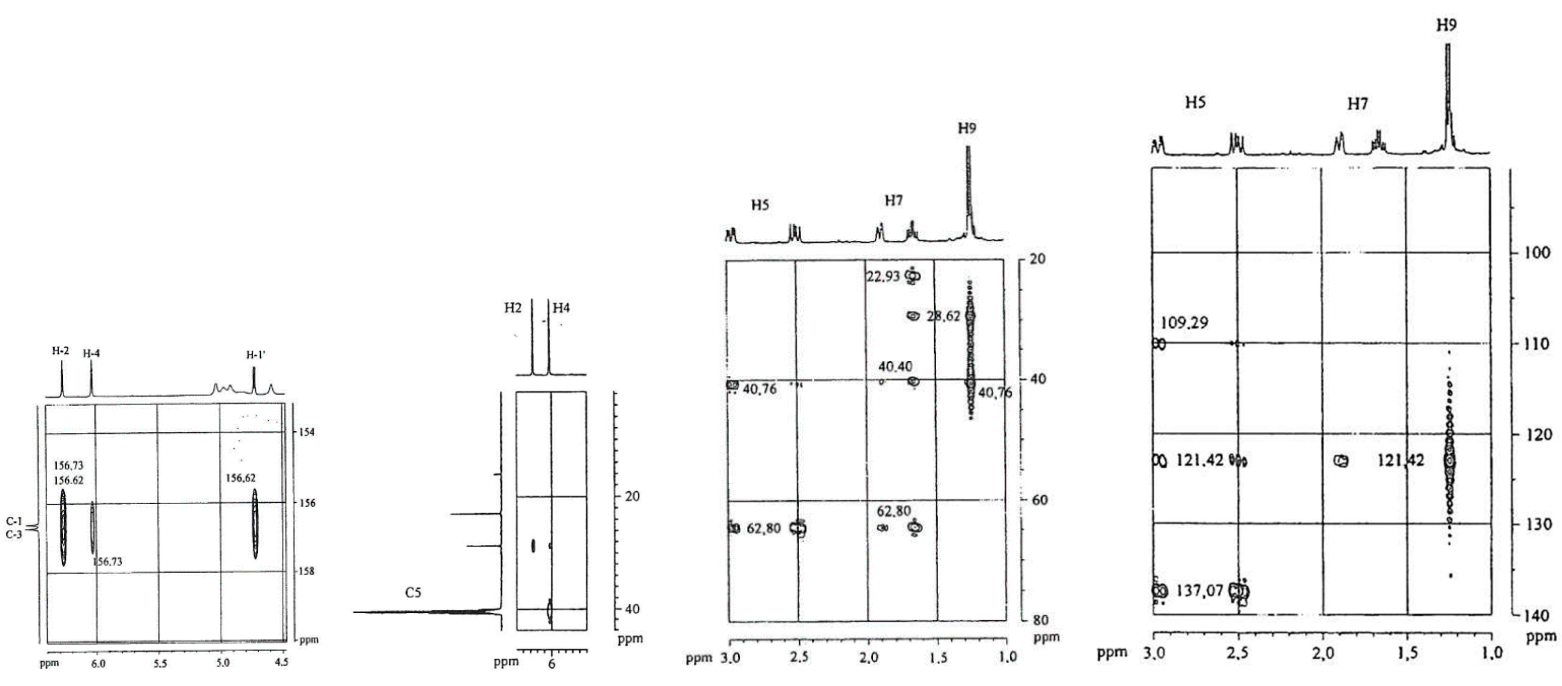

D)
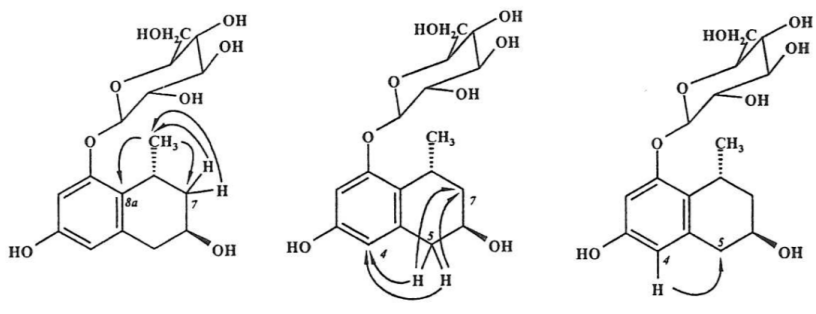

Figure 7. (A) ESI-MS of 9; (B) ${ }^{1} \mathrm{H}$ - (left) and ${ }^{13} \mathrm{C}-\mathrm{NMR}$ spectra (right) of 9; (C) excerpts from its HMBC spectrum; (D) couplings in 9 as presented in the HMBC spectrum. 


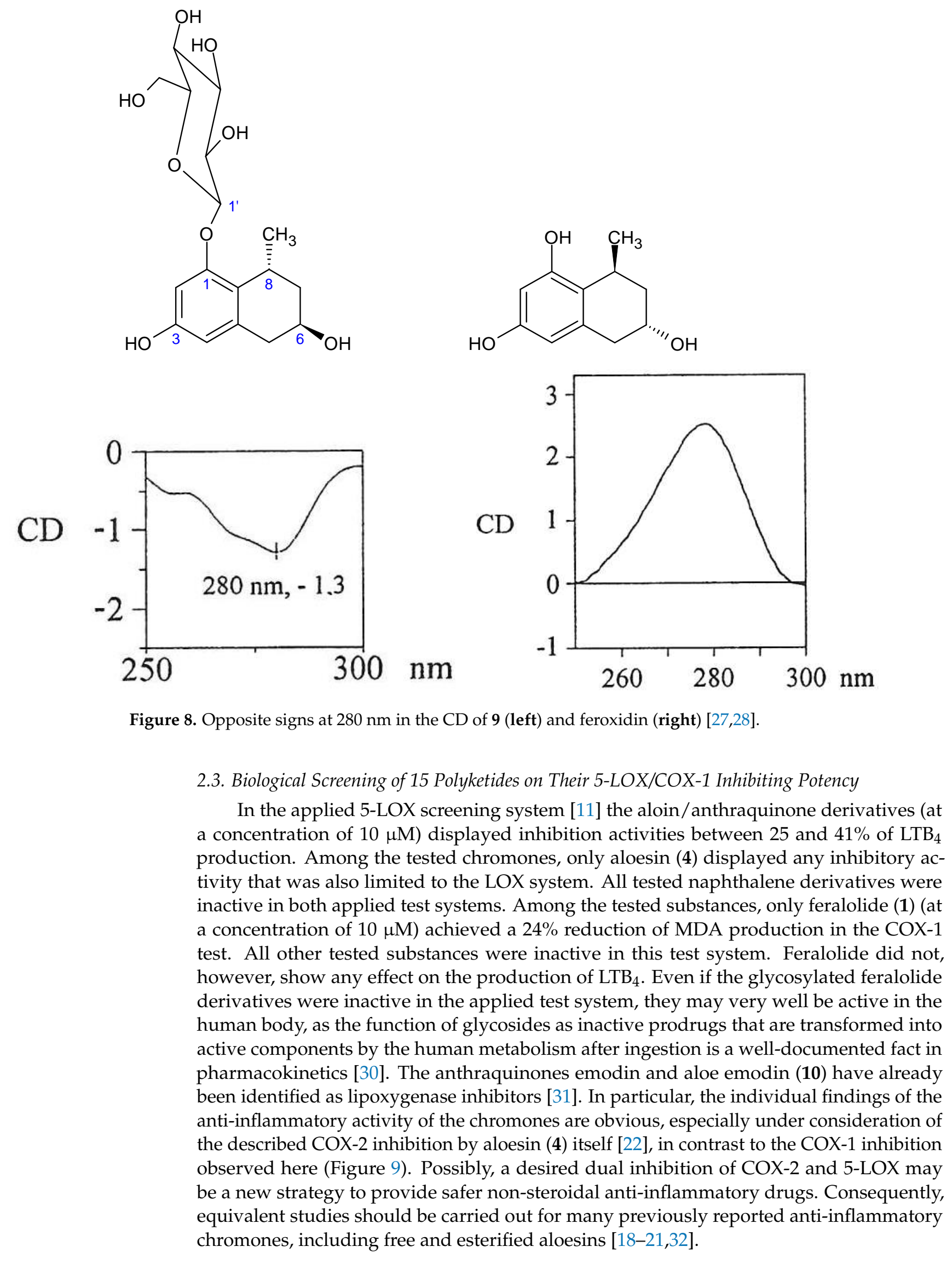




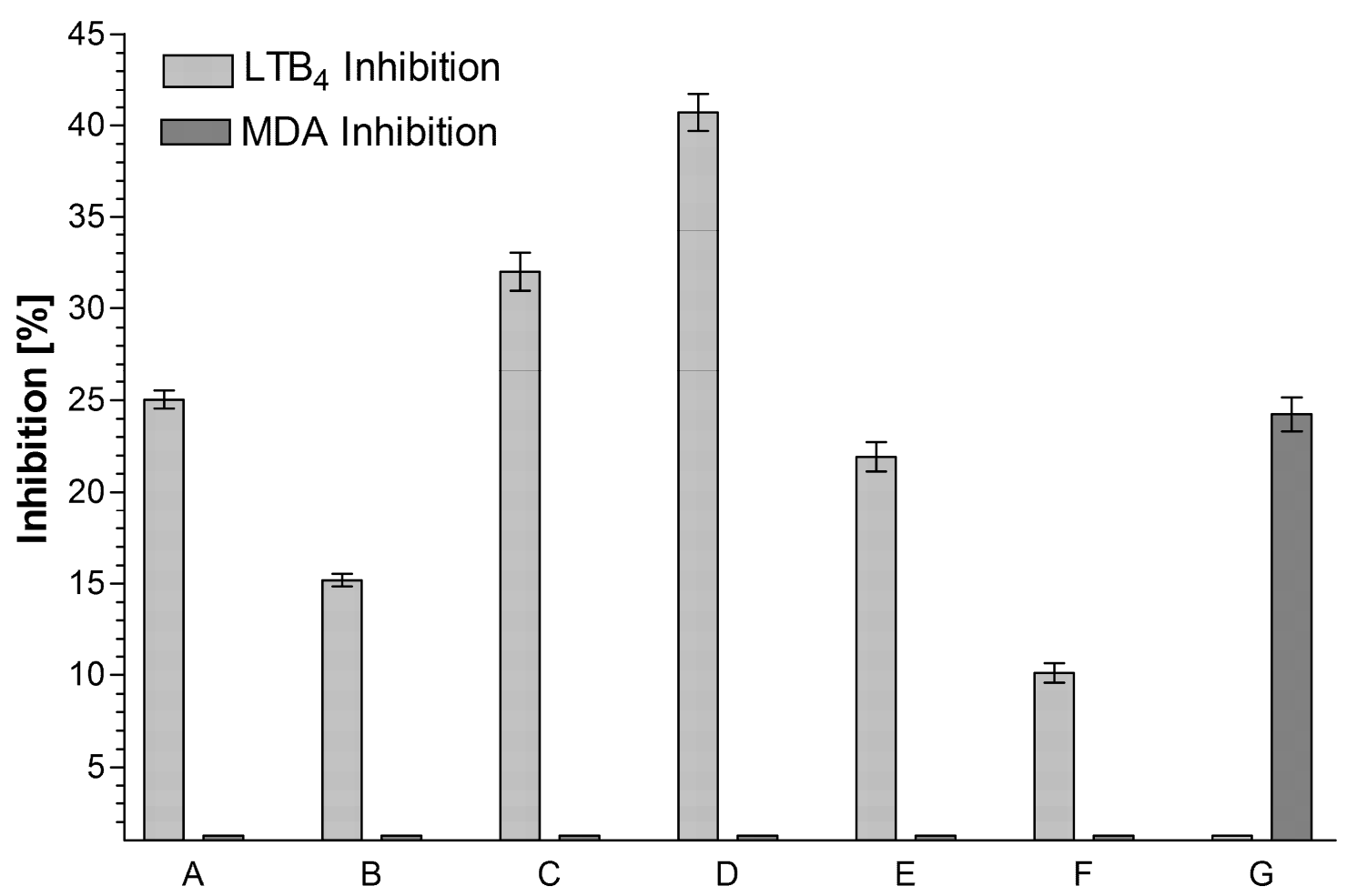

Figure 9. Inhibiting effect of the isolated Aloe polyketide constituents on the biosynthesis of the inflammation mediators $\mathrm{LTB}_{4}$ and MDA in the above described in vitro test systems. Among these, only those that did display activity in at least one of the two test systems are depicted. All measurements were performed in triplicates at a concentration of $10 \mu \mathrm{M}$ for all tested substances (for further details, see Materials and Methods). (A) aloin A/B (25.00\% LTB $_{4}$ inhibition) (11 in Figure 1); (B) aloe emodin (15.00\% $\mathrm{LTB}_{4}$ inhibition) (10 in Figure 1); (C) 6'-O-(E)-coumaroyl-aloin A (32.00\% $\mathrm{LTB}_{4}$ inhibition) (12 in Figure 1); (D) 6'-O-(E)-coumaroyl-aloin B (41.00\% LTB $_{4}$ inhibition) (13 in Figure 1); (E) 6'-O-(E)-coumaroyl-7-hydroxy-8-Omethyl-aloin B (22.00\% $\mathrm{LTB}_{4}$ inhibition) (15 in Figure 1); (F) aloesin (10.00\% LTB 4 inhibition) (4 in Figure 1); (G) 3R-feralolide (24.00\% MDA inhibition) (1 in Figure 1).

Most of these plant polyketides have been isolated, together with related isocoumarins from the Japanese medicinal and recreational tea plant, amacha, meaning "sweet tea" in Japanese (Hydrangea macrophylla Seringe var. thunbergii Makino) [33,34], the naturally sweet taste of which is caused by the dihydroisocoumarin phyllodulcin, with a sweetening effect that is 400-800 times sweeter than sugar [35]. In accordance with its application in Japanese Kampo medicine, several other dihydroisocoumarins from this source-namely, hydrangenol, hydrangenol-8-O-glucoside, (-)-hydrangenol-4'-O-glucoside, thunberginol $\mathrm{C}$, thunberginol $\mathrm{D}$, thunberginol $\mathrm{E}$, and thunberginol $\mathrm{G}$ - have been described to exert substantial anti-allergic and antihistaminic effects [36,37]. Furthermore, its dihydroisocoumarins, 3R-phyllodulcin, thunberginol C, thunberginol D, and thunberginol G, have been found to display differentiation-inducing activities against leukemic cells [38], hinting at a potential application for cancer therapy. The same is true for the dihydroisocoumarin $(3 R, 4 R)-(-)-6$-methoxy-1-oxo-3-pentyl-3,4-dihydro-1H-isochromen-4-yl-acetate, isolated from the Brazilian medicinal plant Xyris pterygoblephara Steud., which showed strong aromatase inhibitory activity in an in vitro breast cancer model [39]. In the traditional medicine of Brazil, this plant is mainly used for diverse dermatological indications, which corresponds to the reported activity of its dihydroisocoumarin $(3 R, 4 R)-(-)-6-$ methoxy-3,4-dihydro-3-n-pentil-4-acethoxy-1H-2-benzopyran-1-one against dermato- parasitic fungi [40]. Most recently, the isolation of a dihydroisocoumarin with activity on the GABA A neuronal receptor from the Moroccan herb Haloxylon scoparium Pomel has also been reported [41].

The documented reduction of MDA production in the COX-1 test by feralolide constitutes the first attribution of biological activity to a dihydroisocoumarin of an Aloe species. 
The presented proof of its anti-inflammatory activity is of high relevance in the context of the typical application of $A$. vera in wound healing and a variety of inflammatory diseases, all of which have been validated by successful clinical studies [42-45] and even meta-analysis [46]. Feralolide might be of especial interest in these dermatological indications, as similar dihydroisocoumarins have been identified as active constituents of Japanese amacha (meaning "sweet tea") (Hydrangea macrophylla Seringe var. thunbergii Makino) [36,37] and the Brazilian Xyris pterygoblephara Steud. [40], both of which are traditionally used against skin inflammations. Although the Aloe spp. dihydroisocoumarins were isolated from the laxative aloe resin drug in the present research project, there is no reason to assume that the presence of these compounds in the living plants should be limited to the resin-storing vessels as described above. They may therefore very well be of high interest in the context of the numerous dermatological applications of the Aloe spp. gel drugs. Furthermore, anticancer activities reported from Brazilian traditional medicine for dihydroisocoumarins in the literature $[38,39]$ might also be of interest for the feralolide derivatives of Aloe spp., as the use of whole leaf macerates of Aloe arborescens Mill. as an anticancer drug is one of its most famous applications in this ethnopharmacological tradition [47]. However, how much dihydroisocoumarins might really contribute to this effect has to be clarified in further, independent experiments.

\section{Material and Methods}

\subsection{Isolation of Pure Dihydroisocoumarins (1, 2, and $\mathbf{3})$}

Aloe barbadensis (syn. A. vera) drug (Ph.Eur.) (Lot No. Tot.J/W27.02.84/038) was obtained from Müggenburg Pflanzliche Rohstoffe (Bad Bramstedt, Germany). For the analysis, $100 \mathrm{~g}$ of the powdered drug were extracted with $2 \mathrm{l}$ of a mixture of EtOAc/ $\mathrm{H}_{2} \mathrm{O}$ $(9: 1, v / v)$ under constant shaking for $17 \mathrm{~h}$. After filtration through a frit for removing insoluble components, the organic and aqueous phases were separated. Afterward, the organic phase was extracted again, first with $100 \mathrm{~mL}$ of water, then with $100 \mathrm{~mL}$ of a saturated aqueous $\mathrm{NaCl}$ solution, and then once again with $100 \mathrm{~mL}$ of water. Finally, the organic phase was dried over $\mathrm{Na}_{2} \mathrm{SO}_{4}$ and subsequently evaporated to dryness under reduced pressure, resulting in $22.8 \mathrm{~g}$ of dry extract. A part of the organic fraction (20 g) was adsorbed to $80 \mathrm{~g}$ of silica gel $(40-63 \mu \mathrm{m})$ and subjected to normal phase silica gel CC $\left(2.1 \mathrm{~kg}, \mathrm{CHCl}_{3}-\mathrm{MeOH}(3: 1, v / v)\right)$ to give nine fractions (Fr.A1 (2.2 g), Fr.A2 (3.5 g), Fr.A3 (4.6 g), Fr.A4 (7.2 g), Fr.A5 (0.8 g), Fr.A6 (0.7 g), Fr.A7 (0.4 g), Fr.A8 (0.3 g), Fr.A9 (0.1 g)). The entire $2.2 \mathrm{~g}$ of Fr.A1 were subjected to HSCCC (MKII CCC, Zinsser Analytics, Frankfurt, Germany) (stationary phase: organic; mobile phase: aqueous; $\left(\mathrm{CHCl}_{3} / \mathrm{MeOH} / \mathrm{H}_{2} \mathrm{O}\right) 7: 13: 8$; $1 \mathrm{~mL} / \mathrm{min}$ ) to give three fractions (Fr.B1 (1.22 g), Fr.B2 (0.75 g), Fr.B3 (0.58 g)). After this, $255 \mathrm{mg}$ of Fr.B2 were subsequently adsorbed to $0.4 \mathrm{~g}$ of silica gel $(40-63 \mu \mathrm{m})$ and subjected to normal phase silica gel $\mathrm{CC}\left(35 \mathrm{~g}, \mathrm{CHCl}_{3}-\mathrm{MeOH}(3: 1, v / v)\right)$, eluting feralolide (1) $(114 \mathrm{mg})$ as a pure compound. Fr.A5 and Fr.A6 were pooled, adsorbed to $5 \mathrm{~g}$ of silica gel $(63-200 \mu \mathrm{m})$ and subjected to normal phase silica gel CC (35 g, EtOAc $\rightarrow$ EtOAc-MeOH $(100 \rightarrow 100: 5, v / v))$ to give seven fractions (Fr.C1 $(95 \mathrm{mg})$, Fr.C2 (180 mg), Fr.C3 (80 mg), Fr.C4 (210 mg), Fr.C5 (120 mg), Fr.C6 (350 mg), Fr.C7 (450 mg)). Fr.A5 and Fr.A6 were pooled and the entire $800 \mathrm{mg}$ subjected to HSCCC (stationary phase: organic; mobile phase: aqueous; $\left(\mathrm{CHCl}_{3} / \mathrm{MeOH} / \mathrm{H}_{2} \mathrm{O}\right) 7: 13: 8 ; 2 \mathrm{~mL} / \mathrm{min}$ ) to give three fractions (Fr.D1 (235 mg), Fr.D2 (90 mg), Fr.D3 (198 mg)). In a final step, fraction Fr.D2 was purified by gradient semipreparative HPLC (Waters 600 Controller and Pump, Waters Tunable Absorbance Detector Model 486) (Nucleosil C18 (Macherey-Nagel, Düren, Germany); $\left.\mathrm{H}_{2} \mathrm{O}-\mathrm{MeOH}(6: 4 \rightarrow 4: 6) 30 \mathrm{~min}\right), 6-\mathrm{O}-\beta$-D-glucopyranosyl-feralolide (3) (36 mg) and $3^{\prime}$ $O-\beta$-D-glucopyranosyl-feralolide (2) (13 mg) as pure compounds, at $\mathrm{Rt}=15 \mathrm{~min}$ and $\mathrm{Rt}=19 \mathrm{~min}$, respectively.

\subsection{TLC Examination}

All extract fractions in the above-described isolation protocol were controlled for the presence of desirable substances using silica gel $60 \mathrm{~F}_{254}$ TCL plates (Merck, Darm- 
stadt, Germany). Depending on the chromatographic properties of the extract fractions encountered during the isolation procedure, either (EtOAc/EtOH/ $\mathrm{H}_{2} \mathrm{O} ; 100: 20: 13$ ) or $\left(\mathrm{CHCl}_{3} / \mathrm{MeOH} / \mathrm{H}_{2} \mathrm{O} / \mathrm{HCOOH}\right.$; 70:130:80:1) was used as mobile phase $\mathrm{A}$ and $\mathrm{B}$, respectively. Detection took place under UV light (quenching at $254 \mathrm{~nm}$ and fluorescence at $366 \mathrm{~nm}$ ) and in the daylight after derivatization with either 5\% methanolic $\mathrm{KOH}$ (after incubation at $105{ }^{\circ} \mathrm{C}$ for $10 \mathrm{~min}$ ) or with a $0.5 \%$ aqueous solution of fast blue B zinc salt (di-o-anisidine diazotatezinc double salt), depending on the properties of the individual extract. When using mobile phase $A, 1,2$, and 3 displayed $R_{f}$ values of $0.96,0.66$, and 0.63 , while the corresponding values for mobile phase B were $0.69,0.32$, and 0.33 , respectively.

\subsection{ESI-MS, NMR and CD Spectra}

As far as the applied NMR instruments are concerned, a Varian (Palo Alto, CA, USA) Gemini 300 Spectrometer $\left({ }^{1} \mathrm{H}: 300.075 \mathrm{MHz},{ }^{13} \mathrm{C}: 75.462 \mathrm{MHz}\right.$ ), a Bruker (Rheinstetten, Germany) Advance DRX-400 Spectrometer $\left({ }^{1} \mathrm{H}: 399.952 \mathrm{MHz},{ }^{13} \mathrm{C}: 100.577 \mathrm{MHz}, \mathrm{HMQC}\right.$ : $160 \mathrm{MHz}, \mathrm{HMBC}: 8 \mathrm{MHz})$, and a Bruker DRX-600 Spectrometer $\left({ }^{1} \mathrm{H}: 600.133 \mathrm{MHz},{ }^{13} \mathrm{C}\right.$ : 150.918 MHz, HMQC: $160 \mathrm{MHz}, \mathrm{HMBC}: 8 \mathrm{MHz}$ ) were used. An internal reference relative to the respective solvent system was used as a standard. The structures of all three isolated compounds were additionally identified via Nuclear Overhauser Effect (NOE) experiments. All mass spectra were recorded using a Sciex 365 API No. 99 MS-MS instrument from Perkin-Elmer (Waltham, MA, USA) in electrospray ionization mode. CD spectra were recorded on a Jasco715-spectrometer (Pfungstadt, Germany).

\subsection{Isolation of 5,6,7,8-Tetrahydro-1-O- $\beta$-D-glucopyranosyl-3,6-dihydroxy-8-methylnaphthalene (9) from Aloe plicatilis}

Fresh leaves of Aloe plicatilis were obtained from the Palmengarten in Frankfurt am Main. For isolation, $242.5 \mathrm{~g}$ of the leaves were cut into cubes of $2 \mathrm{~cm}$ diameter and homogenized in an Ultra Turrax T50 for $1 \mathrm{~h}$ under cooling with ice in $500 \mathrm{~mL}$ methanol. After filtration, the resulting extract was evaporated to dryness in a vacuum (fraction A, $4.3 \mathrm{~g}$ ). The remaining plant material is homogenized for $1 \mathrm{~h}$ with $250 \mathrm{~mL}$ water and $250 \mathrm{~mL}$ methanol. After filtration, the resulting extract is evaporated to dryness in a vacuum (fraction B, $1.6 \mathrm{~g}$ ). Then, $4.2 \mathrm{~g}$ of fraction A were suspended in $50 \mathrm{~mL}$ methanol. After removing the insoluble parts, the liquid extract was evaporated to dryness in a vacuum, yielding $2.44 \mathrm{~g}$ of dry extract. This extract was divided into two equal portions and separated using two identical CC setups (column A: silica gel 40-63 $\mu \mathrm{m}$, liquid phase: EtOAc 100 mL, EtOAc/MeOH (10:1) 200 mL, EtOAc/MeOH (10:2) 200 mL, EtOAc/MeOH (10:3) $200 \mathrm{~mL}, \mathrm{EtOAc} / \mathrm{MeOH}(10: 4) 200 \mathrm{~mL})$. During this CC, two fractions could be identified via TLC detection, namely, fraction $1\left(0.13 \mathrm{~g} / \mathrm{R}_{\mathrm{f}}\left(\mathrm{SiO}_{2}\right): 0.47\left(\mathrm{EtOAc} / \mathrm{MeOH} / \mathrm{H}_{2} \mathrm{O}\right.\right.$ 100:17:13)) and fraction 2 (0.25 g/ $\mathrm{R}_{\mathrm{f}}\left(\mathrm{SiO}_{2}\right)$ : 0.11 (EtOAc/MeOH/H$/ \mathrm{H}_{2} \mathrm{O}$ 100:17:13)). Subsequently, plicataloside (8) $\left(0.12 \mathrm{~g} / \mathrm{R}_{\mathrm{f}}\left(\mathrm{SiO}_{2}\right)\right.$ : 0.09 (EtOAc/MeOH/H$/ \mathrm{H}_{2} \mathrm{O}$ 100:20:13)/0.15 $\left(\mathrm{CH}_{3} \mathrm{Cl}_{3} / \mathrm{MeOH} / \mathrm{H}_{2} \mathrm{O} / \mathrm{HCOOH}\right.$ 7:13:8:0.1)) was isolated via $\mathrm{CC}$ of $0.24 \mathrm{~g}$ of fraction 2 with Sephadex LH 20 and methanol as a mobile phase, as a pure, solid yellow substance. Likewise, 5,6,7,8-tetrahydro-1-O- $\beta$-D-glucopyranosyl-3,6-dihydroxy-8- methylnaphthalene (9) (58 mg/ $\mathrm{R}_{\mathrm{f}}\left(\mathrm{SiO}_{2}\right): 0.59$ (EtOAc/EtOH/H $\left.\mathrm{H}_{2} \mathrm{O} 100: 20: 13\right) / 0.19\left(\mathrm{CH}_{3} \mathrm{Cl}_{3} / \mathrm{MeOH} / \mathrm{H}_{2} \mathrm{O} / \mathrm{HCOOH}\right.$ 7:13:8:0.1)) was isolated via CC of $0.11 \mathrm{~g}$ of fraction 1 on Sephadex LH 20 and methanol as a mobile phase, and also as a pure, solid yellow substance.

\subsection{In Vitro Screening for Anti-Inflammatory Activity by Inhibiting COX-1 (MDA Assay)}

During the catalysis of $\mathrm{PGH}_{2}$ (prostaglandin $\mathrm{H} 2$ ) into $\mathrm{TXA}_{2}$ (thromboxane A2) by the thromboxane synthase system, malondialdehyde (MDA) is produced at a ratio of 1:1 with 12-HHT (12(S)-hydroxyheptadeca-5Z, 8E, 10E-trienoic acid). MDA can be detected photometrically after aldol condensation with thiobutyric acid [48]. For the in vitro screening, $1.5 \mathrm{l}$ of pig blood was collected in a plastic bucket that already contained $150 \mathrm{~mL}$ of sodium-EDTA solution $(0.077 \mathrm{M})$, immediately after sacrificing the animal. The blood was diluted with $700 \mathrm{~mL}$ of isotonic PBS (phosphate-buffered saline) solution and centrifuged for $20 \mathrm{~min}$ at $200 \times \mathrm{g}$. The supernatant, which is rich in thrombocytes, was carefully 
collected using a syringe and centrifuged once again for $20 \mathrm{~min}$ at $200 \times g$ to remove all remaining erythrocytes. In the subsequent centrifugation step at $1000 \times g$ for $15 \mathrm{~min}$, the thrombocytes sediment and can finally be re-suspended in isotonic PBS at a defined cell density of $10^{9}$ cells $/ \mathrm{mL}$. All isolation steps can be performed in plastic vessels at room temperature. For the test, $700 \mu \mathrm{L}$ of this thrombocyte suspension was placed in $1.5 \mathrm{~mL}$ Eppendorf vessels (Eppendorf AG, Hamburg, Germany), together with $10 \mu \mathrm{L}$ of the respective inhibitor solution, and incubated for $10 \mathrm{~min}$ at $37^{\circ} \mathrm{C}$. The enzyme reaction was started by adding $50 \mu \mathrm{L}$ of calcium ionophore buffer (final concentration: $5 \mu \mathrm{M}$ ) and terminated after $10 \mathrm{~min}$ at $37^{\circ} \mathrm{C}$ by adding $400 \mu \mathrm{L}$ of trichloroacetic acid. All samples were centrifuged at $4000 \times g$ for $15 \mathrm{~min}$, after which the supernatant was used for determining the MDA concentration. A negative control was performed in four repetitions, in which only $10 \mu \mathrm{L}$ of DMSO solvent were added to the reaction mixture instead of the respective isolated compounds. For the positive control $(n=2), 700 \mu \mathrm{L}$ of thrombocyte suspension was mixed with $10 \mu \mathrm{L}$ of solvent and incubated at $37^{\circ} \mathrm{C}$. After $10 \mathrm{~min}, 400 \mu \mathrm{L}$ of trichloroacetic acid and subsequently $50 \mu \mathrm{L}$ of calcium ionophore buffer were added to the mixture. The subsequent steps were identical to those described for the extracted Aloe constituents, as described above. For determining the MDA concentration, $0.5 \mathrm{~mL}$ of the abovementioned supernatant was mixed with $0.5 \mathrm{~mL}$ of thiobarbituric acid solution. This mixture was incubated in a water bath for $30 \mathrm{~min}$ at $70{ }^{\circ} \mathrm{C}$. After another $30 \mathrm{~min}$ of incubation at room temperature, the amount of MDA was measured in a spectral fluorometer $(\lambda$-excitation: $533 \mathrm{~nm}, \lambda$-emission: $550 \mathrm{~nm}$ ).

\subsection{In Vitro Screening for Anti-Inflammatory Activity by Inhibiting 5-LOX ( $\mathrm{LTB}_{4}$ Assay)}

For the $\mathrm{LTB}_{4}$ (Leukotriene B4) test, the products of the arachidonic acid production can be directly measured via HPLC after the enzyme reaction in the thrombocytes and the subsequent activation reaction have taken place. The produced amounts of $\mathrm{LTB}_{4}$ and 5-HETE (5-Hydroxyeicosatetraenoic acid) were directly detected at $270 \mathrm{~nm}$, revealing the inhibitory potential of the tested substance (inhibition by zileuton as positive control). For the screening, 1.0 L of cow blood was collected in a plastic bucket that already contained $100 \mathrm{~mL}$ of sodium-EDTA solution $(0.077 \mathrm{M})$ as an anticoagulant, immediately after sacrificing the animal. The blood was centrifuged at $200 \times g$ for $20 \mathrm{~min}$, after which the thrombocytes containing the supernatant were separated. In order to facilitate the lyses of the erythrocytes, the remaining pellet was re-suspended in $800 \mathrm{~mL}$ of water. After $30 \mathrm{~s}$ of incubation, $400 \mathrm{~mL}$ of hypertonic PBS solution was added, followed by another centrifugation step at $485 \times g$ for $10 \mathrm{~min}$. The resulting cell pellet was re-suspended in $50 \mathrm{~mL}$ of isotonic PBS solution and transferred to $20 \mathrm{~mL}$ of Histo-Paque (Sigma Aldrich, Taufkirchen, Germany). After yet another centrifugation for $45 \mathrm{~min}$ at $675 \mathrm{~g}$, lymphocytes and macrophages that did not sediment in this setup were removed, while the granulocyte pellet was re-suspended in $10 \mathrm{~mL}$ of isotonic PBS solution. After an additional washing step in isotonic PBS solution, the granulocytes were re-suspended in $\mathrm{O}_{2}$-saturated, isotonic PBS solution, which had been continuously stirred on a magnetic stirrer at maximum speed for $5 \mathrm{~min}$, at an exact cell density of $6 \times 10^{7}$ cells per $\mathrm{ml}$. Although this granulocyte isolation protocol was performed at room temperature, the light exposure of the cells had to be limited as much as possible. For the enzyme reaction, a glass centrifuge tube was filled with $2.5 \mu \mathrm{L}$ of the Aloe constituent test solution, or $2.5 \mu \mathrm{L}$ of DMSO for the kinetic and control measurements. Subsequently, the tubes were filled with $0.8 \mathrm{~mL}$ of the above-described granulocyte suspension and incubated for $5 \mathrm{~min}$ at $37^{\circ} \mathrm{C}$ in the water bath under constant shaking. Thereafter, $0.2 \mathrm{~mL}$ of calcium chloride was added, followed by an additional $5 \mathrm{~min}$ of incubation at $37^{\circ} \mathrm{C}$. In the next step, leukotriene production was induced by the addition of $2.5 \mu \mathrm{L}$ of calcium ionophore buffer to the reaction mixture. After an additional $5 \mathrm{~min}$ (this variable was varied, respectively, in the case of the kinetic measurements) of incubation at $37^{\circ} \mathrm{C}$, the enzyme reaction was terminated by adding $1 \mathrm{~mL}$ of a solution of acetonitrile/methanol (1:1) that contains NDGA (nordihydroguaiaretic acid) as an antioxidant and $\mathrm{PGB}_{2}$ (prostaglandin B2) as an internal standard. All glass centrifuge tubes were put into an 
ice-water bath immediately after termination of the reaction, sealed, and incubated in the ice-water bath for $20 \mathrm{~min}$. Thereafter, centrifugation was performed for $15 \mathrm{~min}$ at $4000 \times \mathrm{g}$ under constant cooling at $4{ }^{\circ} \mathrm{C}$. The supernatants were filled into vials, which were flanged and stored at $-20^{\circ} \mathrm{C}$ for further preparation. Each incubation setup contained 4 control and 8 sample measurements. Each defrosted sample was diluted with $10 \mathrm{~mL}$ of water and applied to an RP octadecyl extraction column (Macherey-Nagel, Düren, Germany), which had previously been washed successively with $10 \mathrm{~mL} \mathrm{MeOH}, 5 \mathrm{~mL}$ water, and $5 \mathrm{~mL}$ of a $0.1 \%$ EDTA solution. After washing the column two times with $5 \mathrm{~mL}$ of water, the adsorbed substances were eluted with $3 \mathrm{~mL}$ of $\mathrm{MeOH}$. This eluate was diluted with $3 \mathrm{~mL}$ of water. Subsequently, the concentration of $\mathrm{LTB}_{4}$ was directly measured by HPLC using a Nucleosil $7 \mu \mathrm{m}$ C18 column $(250 \mathrm{~mm} \times 4.6 \mathrm{~mm})$ (Macherey-Nagel, Düren, Germany) with tetrahydrofuran/MeOH/aqueous EDTH solution $(0.1 \%) /$ acetic acid $(25: 30: 45: 0.1 ; v / v)$, pH 5.5 (conc. $\mathrm{NH}_{4}$ aq) as a mobile phase, at a flow rate of $0.9 \mathrm{~mL} / \mathrm{min}$. UV detection took place at $270 \mathrm{~nm}$. For measuring the 5-HETE concentration, only the mobile phase was changed to $\mathrm{MeOH} / \mathrm{H}_{2} \mathrm{O} /$ acetic acid $(77: 23: 0.1 ; v / v), \mathrm{pH} 5.5$ (conc. $\mathrm{NH}_{4}$ aq) with a flow rate of $1.0 \mathrm{~mL} / \mathrm{min}$. UV detection took place at $232 \mathrm{~nm}$. The inhibition of the 5-lipoxygenase systems was then calculated from the measured amounts of $\mathrm{LTB}_{4}$ and 5-HETE. The relative concentration of $\mathrm{LTB}_{4} / 5$-HETE in each sample equals the ratio of the peak areas of $\mathrm{LTB}_{4} / 5$-HETE, relative to the internal standard $\mathrm{PGB}_{2}$. The inhibition of the 5-lipoxygenase system, therefore, equals the ratio between the $\mathrm{LTB}_{4} / 5$-HETE value in the presence and in the absence of the respective Aloe constituent.

Author Contributions: H.W.R.-Conceptualization; Data curation; Funding acquisition; Project administration; Validation and major Writing of the original draft; R.M.--Investigation (doctoral thesis, Leipzig University), Software and Validation; G.D.-LOX/COX Investigation and Methodology; K.K.-Data curation; Software and Writing of the original draft. All authors have read and agreed to the published version of the manuscript.

Funding: This research received no external funding.

Data Availability Statement: The data presented in this study are available in this article.

Acknowledgments: The authors would like to thank the Palmengarten, Frankfurt am Main, for the kind gift of Aloe plicatilis plant material; L. Hennig (Institute of Analytical Chemistry, Leipzig University) and J. Ortwein (Department Pharmaceutical/Medicinal Chemistry, Leipzig University) for recording ESI-MS and NMR spectra; P. Welzel and J. Zontsma (Institute of Organic Chemistry, Leipzig University) for instructions on the performing and recording of the CD spectra.

Conflicts of Interest: The authors declare no conflict of interest.

Sample Availability: Samples of the compounds are partially available from HWR and RM.

$\begin{array}{ll}\text { Abbreviation } \\ \text { CC } & \text { Column chromatography } \\ \text { CD } & \text { Circular dichroism } \\ \text { COX-1 } & \text { Cyclooxygenase-1 } \\ \text { ESI-MS } & \text { Electrospray-ionization mass-spectrometry } \\ \text { HMBC } & \text { Heteronuclear multiple-bond correlation spectroscopy } \\ \text { HMQC } & \text { Heteronuclear multiple-quantum correlation spectroscopy } \\ \text { HSCCC } & \text { High-speed countercurrent chromatography } \\ \text { 5-LOX } & \text { 5-lipoxygenase } \\ \text { LTB4 } & \text { Leukotriene B4 } \\ \text { MDA } & \text { Malondialdehyde }\end{array}$

\section{References}

1. Reynolds, T. Editor: The Genus Aloe; CRC Press: Boca Raton, FL, USA, 2004; p. 39.

2. Beil, A.; Rauwald, H.W. Aloe. In Hagers Handbuch der Pharmazeutischen Praxis, 5th ed.; Hänsel, R., Keller, K., Rimpler, H., Schneider, G., Eds.; Springer: Berlin, Germany, 1992; Volume 4, pp. 209-232. 
3. Rauwald, H.W.; Maucher, R.; Niyonzima, D.D. Three 8-C-glucosyl-5-methyl-chromones from Aloe barbadensis (Ph. Eur. 1997). Pharmazie 1997, 52, 962-964.

4. Rauwald, H.W.; Lohse, K.; Bats, J.W. Bestimmung der Konfiguration der beiden diastereomeren C-Glucosylanthrone Aloin A und B. Angew. Chem. 1989, 101, 1539-1540. [CrossRef]

5. Rauwald, H.W.; Sigler, A. Simultaneous determination of 18 polyketides typical of Aloe by high performance liquid chromatography and photodiode array detection. Phytochem. Anal. 1994, 5, 266-270. [CrossRef]

6. Sigler, A.; Rauwald, H.W. Aloe Plants Accumulate Anthrone-Type Anthranoids in Inflorescence and Leaves, and Tetrahydroanthracenes in Roots. Zeitschrift für Naturforschung 1994, 49, 286-292. [CrossRef]

7. Rauwald, H.W. Naturally occurring quinones and their related reduction forms: Analysis and analytical methods. PZ Wissenschaft. 1990, 3, 169-181.

8. Dannhardt, G.; Lehr, M. In-vitro evaluation of 5-lipoxygenase and cyclo-oxygenase inhibitors using bovine neutrophils and platelets and HPLC. J. Pharm. Pharmacol. 1992, 44, 419-424. [CrossRef] [PubMed]

9. Dannhardt, G.; Kiefer, W. Cyclooxygenase inhibitors-current status and future prospects. Eur. J. Med. Chem. 2001, 36, 109-126. [CrossRef]

10. Dannhardt, G.; Ulbrich, H. In-vitro test system for the evaluation of cyclooxygenase-1 (COX-1) and cyclooxygenase-2 (COX-2) inhibitors based on a single HPLC run with UV detection using bovine aortic coronary endothelial cells (BAECs). Inflamm. Res. 2001, 50, 262-269. [CrossRef]

11. Dannhardt, G.; Schneider, G.; Schwell, B. Identification and 5-lipoxygenase inhibiting potency of medicarpin isolated from roots of Ononis spinosa L. Pharma. Pharmacol. Lett. 1992, 2, 161-162.

12. Speranza, G.; Manitto, P.; Cassarà, P.; Monti, D. Feralolide, a dihydroisocoumarin from cape aloe. Phytochemistry 1993, 33, 175-178. [CrossRef]

13. Veitch, N.C.; Simmonds, M.S.J.; Blaney, W.M.; Reynolds, T. A dihydroisocoumarin glucoside from Aloe hildebrandtii. Phytochemistry 1994, 35, 1163-1166. [CrossRef]

14. Maucher, R.; Rauwald, H.W.; Niyonzima, D.D. Three 8-C-glucosylchromones and two dihydroisocoumarins from Aloe barbadensis (DAB 1996). In Proceedings of the 45th Annual Congress of the Society of Medicinal Plant Research, Regensburg, Germany, 7-12 September 1997. Conference booklet: C25.

15. Maucher, R.; Rauwald, H.W. Stereoselective resolution and characterisation of dihydroisocoumarin glycosides from Aloe vera. In Proceedings of the 5th Joint Meeting of ASP, AFERP, GA, PSE: 2000 Years of Natural Products Research, Past, Present and Future, Amsterdam, The Netherlands, 26-30 July 1999. Conference booklet.

16. Kurizaki, A.; Watanabe, T.; Devkota, H.P. Chemical Constituents from the Flowers of Aloe arborescens. Nat. Prod. Commun. 2019, 14. [CrossRef]

17. Choi, J.S.; Lee, S.K.; Sung, C.K.; Jung, J.H. Phytochemical Study of Aloe vera. Arch. Pharm. Res. 1996, 19, 163-167. [CrossRef]

18. Abd-Alla, H.I.; Shaaban, M.; Shaaban, K.A.; Abu-Gabal, N.S.; Shalaby, N.M.; Laatsch, H. New bioactive compounds from Aloe hijazensis. Nat. Prod. Res. 2009, 23, 1035-1049. [CrossRef] [PubMed]

19. Hutter, J.A.; Salman, M.; Stavinoha, W.B.; Satsangi, N.; Williams, R.F.; Streeper, R.T.; Weintraub, S.T. Antiinflammatory C-glucosyl chromones from Aloe barbadensis. J. Nat. Prod. 1996, 59, 541-543. [CrossRef] [PubMed]

20. Lee, K.Y.; Weintraub, S.T.; Yu, B.P. Isolation and identification of a phenolic antioxidant from Aloe barbadensis. Free Radic. Biol. Med. 2000, 28, 261-265. [CrossRef]

21. Speranza, G.; Morelli, C.F.; Tubaro, A.; Altinier, G.; Durì, L.; Manitto, P. Aloeresin I, an anti-inflammatory 5-methylchromone from cape aloe. Planta Med. 2005, 71,79-81. [CrossRef]

22. Yagi, A.; Kabash, A.; Okamura, N.; Haraguchi, H.; Moustafa, S.M.; Khalifa, T.I. Antioxidant, free radical scavenging and anti-inflammatory effects of aloesin derivatives in Aloe vera. Planta Med. 2002, 68, 957-960. [CrossRef] [PubMed]

23. Bisrat, D.; Dagne, E.; van Wyk, B.E.; Viljoen, A. Chromones and anthrones from Aloe marlothii and Aloe rupestris. Phytochemistry 2000, 55, 949-952. [CrossRef]

24. Rauwald, H.W.; Beil, A. High-performance liquid chromatographic separation and determination of diastereomeric anthrone-Cglucosyls in Cape aloes. J. Chromatogr. A 1993, 639, 359-362. [CrossRef]

25. Aldayel, T.S.; Grace, M.H.; Lila, M.A.; Yahya, M.A.; Omar, U.M.; Alshammary, G. LC-MS characterization of bioactive metabolites from two Yemeni Aloe spp. with antioxidant and antidiabetic properties. Arab. J. Chem. 2020, 13, 5040-5049. [CrossRef]

26. Mikayoulou, M.; Mayr, F.; Temml, V. Anti-tyrosinase activity of South African Aloe species and isolated compounds plicataloside and aloesin. Fitoterapia 2021, 150, 104828. [CrossRef] [PubMed]

27. Speranza, G.; Manitto, P.; Monti, D.; Lianza, F. Feroxidin, a novel 1-methyltetralin derivative isolated from cape aloe. Tetrahedron Lett. 1990, 31, 3077-3080. [CrossRef]

28. Speranza, G.; Manitto, P.; Pezzuto, D.; Monti, D. Absolute configuration of feroxidin: An experimental support to Snatzke's helicity rules for tetralins. Chirality 1991, 3, 3263-3267. [CrossRef]

29. Speranza, G.; Manitto, P.; Monti, D.; Pezzuto, D. Studies on Aloe, Part 10. Feroxins A and B, two O glucosylated 1-methyltetralins from Cape aloe. J. Nat. Prod. 1992, 55, 723-729. [CrossRef]

30. Hanske, L.; Loh, G.; Sczesny, S.; Blaut, M.; Braune, A. The bioavailability of apigenin-7-glucoside is influenced by human intestinal microbiota in rats. J. Nutr. 2009, 139, 1095-1102. [CrossRef] 
31. Malterud, K.E.; Farbrot, T.L.; Huse, A.E.; Sund, R.B. Antioxidant and radical scavenging effects of anthraquinones and anthrones. Pharmacology 1993, 47 (Suppl. 1), 77-85. [CrossRef]

32. Silva, C.F.; Pinto, D.C.; Silva, A.M. Chromones: A Promising Ring System for New Anti-inflammatory Drugs. ChemMedChem 2016, 11, 2252-2260. [CrossRef]

33. Yoshikawa, M.; Ueda, T.; Shimoda, H.; Murakami, T.; Yamahara, J.; Matsuda, H. Dihydroisocoumarin constituents from the leaves of Hydrangea macrophylla var. thunbergii (2). Absolute stereostructures of hydrangenol, thunberginol I, and phyllodulcin glycosides and isomerization reaction at the 3-positions of phyllodulcin and its glycosides. Chem. Pharm. Bull. 1999, 47, 383-387.

34. Liu, J.; Nakamura, S.; Zhuang, Y. Medicinal flowers 40: Structures of dihydroisocoumarin glycosides and inhibitory effects on aldose reducatase from the flowers of Hydrangea macrophylla var.thunbergii. Chem. Pharm. Bull. 2013, 61, 655-661. [CrossRef]

35. Tomasik, P. (Ed.) Chemical and Functional Properties of Food Saccharides (Chemical \& Functional Properties of Food Components; CRC Press: Boca Raton, FL, USA, 2003; Volume 5.

36. Matsuda, H.; Shimoda, H.; Yamahara, J.; Yoshikawa, M. Effects of phyllodulcin, hydrangenol, and their 8-O-glucosides, and thunberginols A and F from Hydrangea macrophylla SERINGE var. thunbergii MAKINO on passive cutaneous anaphylaxis reaction in rats. Biol. Pharm. Bull. 1999, 22, 870-872. [CrossRef] [PubMed]

37. Yoshikawa, M.; Matsuda, H.; Shimoda, H.; Shimada, H.; Harada, E.; Naitoh, Y.; Miki, A.; Yamahara, J.; Murakami, N. Development of bioactive functions in Hydrangeae dulcis folium. V. On the antiallergic and antimicrobial principles of Hydrangeae dulcis folium. (2). Thunberginols C, D, and E, thunberginol G 3'-O-glucoside, (-)-hydrangenol 4'-o-glucoside, and (+)-hydrangenol 4'-O-glucoside. Chem. Pharm. Bull. 1996, 44, 1440-1447.

38. Umehara, K.; Matsumoto, M.; Nakamura, M.; Miyase, T.; Kuroyanagi, M.; Noguchi, H. Differentiation inducing activities of isocoumarins from Hydrangea Dulcis Folium. Chem. Pharm. Bull. 2000, 48, 566-567. [CrossRef]

39. Endringer, D.C.; Guimarães, K.G.; Kondratyuk, T.P.; Pezzuto, J.M.; Braga, F.C. Selective inhibition of aromatase by a dihydroisocoumarin from Xyris pterygoblephara. J. Nat. Prod. 2008, 71, 1082-1084. [CrossRef]

40. Guimarães, K.G.; de Souza Filho, J.D.; Dos Mares-Guia, T.R.; Braga, F.C. Dihydroisocoumarin from Xyris pterygoblephara active against dermatophyte fungi. Phytochemistry 2008, 69, 439-444. [CrossRef]

41. Li, Y.; Plitzko, I.; Zaugg, J.; Hering, S.; Hamburger, M. HPLC-based activity profiling for GABA(A) receptor modulators: A new dihydroisocoumarin from Haloxylon scoparium. J. Nat. Prod. 2010, 73, 768-770. [CrossRef]

42. Syed, T.A.; Ahmad, S.A.; Holt, A.H.; Ahmad, S.A.; Ahmad, S.H.; Afzal, M. Management of psoriasis with Aloe vera extract in a hydrophilic cream: A placebo-controlled, double-blind study. Trop. Med. Int. Health 1996, 1, 505-509. [CrossRef]

43. Langmead, L.; Feakins, R.M.; Goldthorpe, S.; Holt, H.; Tsironi, E.; De Silva, A.; Jewell, D.P.; Rampton, D.S. Randomized, double-blind, placebo-controlled trial of oral Aloe vera gel for active ulcerative colitis. Aliment Pharm. Ther. 2004, 19, 739-747. [CrossRef] [PubMed]

44. Krishnan, P. The scientific study of herbal wound healing therapies: Current state of play. Curr. Anaesth. Crit. Care 2006, 17, 21-27. [CrossRef]

45. Moghbel, A.; Ghalambor, A.; Allipanah, S. Wound Healing and Toxicity Evaluation of Aloe vera Cream on Outpatients with Second Degree Burns. Iran. J. Pharm. Sci. 2007, 3, 157-160.

46. Maenthaisong, R.; Chaiyakunapruk, N.; Niruntraporn, S.; Kongkaew, C. The efficacy of Aloe vera used for burn wound healing: A systematic review. Burns 2007, 33, 713-718. [CrossRef] [PubMed]

47. Zago, R. Cancer Can Be Cured! Waid Group Inc.: Houston, TX, USA, 2000.

48. Ledergerber, D.; Hartmann, R.W. Development of a screening assay for the in vitro evaluation of thromboxane A2 synthase inhibitors. J. Enzym. Inhib. 1995, 9, 253-261. [CrossRef] [PubMed] 